\title{
A survey of the Annamese Lowlands, Vietnam, and its implications for the conservation of Vietnamese and Imperial Pheasants Lophura hatinhensis and L. imperialis
}

\author{
JONATHAN C. EAMES, FRANK R. LAMBERT and NGUYEN CU
}

\begin{abstract}
Summary
During June and July 1994, five sites in the Annamese Lowlands Endemic Bird Area were surveyed for restricted-range and globally threatened birds, with the ultimate aim of identifying a suitable area for protected area establishment to safeguard populations of endemic Lophura pheasants. Vietnamese Pheasant L. hatinhensis was found at two sites situated less than $10 \mathrm{~km}$ apart, although only regularly encountered in one area, the Net River watershed, Quang Binh province. No conclusive evidence was found of the existence of Imperial Pheasant L. imperialis at any site, although it almost certainly also occurs in the Net River watershed or close by. Where they occur, logging and hunting pose the most serious threats to the long-term survival of these endemic pheasants. Although previously believed to be largely confined to forest in flatter areas, evidence collected during the surveys suggests that $L$. hatinhensis is commonest on ridgetops and slopes in areas with relatively undisturbed, closed-canopy forest. Hence, a major recommendation of this study is that conservation areas for this species should include the maximum extent possible of closed-canopy or lightly logged forest that includes hilly terrain as well as lower-lying, flat areas. The most appropriate area for designation as a protected area was identified as forest in the Net River watershed. It is recommended that a full feasibility study for the establishment of such an area be undertaken as a priority, and that meanwhile a moratorium on legal logging activities and efforts to curtail illegal logging and hunting be implemented by Vietnam's Ministry of Forestry.
\end{abstract}

\section{Introduction}

The government of Vietnam has resolved to establish a network of protected areas throughout the country. However, although most of the areas so far chosen are representative of the fauna and flora, gaps exist within the network and not all of Vietnam's distinctive ecotypes and the habitats of certain globally threatened and endemic species of bird are represented.

A recent study by BirdLife International (ICBP 1992) mapped the distribution of all bird species with global ranges of less than $50,000 \mathrm{~km}^{2}$ (a quarter of the world's birds), determining where clusters of such "restricted-range" species occur, thereby revealing 221 centres of bird endemism or so-called Endemic Bird Areas (EBAs). An underlying premise of the work is that these key areas of bird endemism may also be important for other endemic taxa and this is, to some degree, supported by the limited available data (Thirgood and Heath 1994). The identification these endemic bird areas will, it is hoped, assist conservation planners when establishing protected-area programmes. 
Table 1. Habitat requirements of restricted-range birds in the Annamese Lowlands EBA

\begin{tabular}{|c|c|c|c|c|}
\hline Species & Status & Threat & Altitude (m) & Habitat \\
\hline Arborophila merlini & $\mathrm{E}$ & & up to 1,400 & Evergreen forest; secondary growth \\
\hline Lophura edwardsi & $\mathrm{E}$ & C & up to 400 & Evergreen forest \\
\hline Lophura hatinhensis & $\mathrm{E}$ & $\mathrm{E}$ & up to 200 & Evergreen forest; secondary growth \\
\hline Lophura imperialis & $\mathrm{E}$ & $\mathrm{C}$ & up to 200 & Evergreen forest \\
\hline Rheinardia ocellata & & $\mathrm{V}$ & up to 1,500 & Evergreen forest; secondary growth \\
\hline Garrulax vassali & & & $600-2,900$ & $\begin{array}{l}\text { Evergreen forest; secondary growth; } \\
\text { scrub; grassland }\end{array}$ \\
\hline Jabouilleia danjoui & & $\mathrm{V}$ & $50-900$ & $\begin{array}{l}\text { Evergreen forest; secondary and } \\
\text { logged forest; bamboo }\end{array}$ \\
\hline Stachyris herberti & & $\mathrm{V}$ & $50-200$ & Evergreen forest on limestone \\
\hline Macronous kelleyi & & NT & up to 700 & $\begin{array}{l}\text { Evergreen forest; secondary and } \\
\text { logged forest; bamboo }\end{array}$ \\
\hline
\end{tabular}

Status: E, Endemic to Annamese Lowlands EBA. Threat category: globally threatened species are assigned four categories: C, Critical; E, Endangered; V, Vulnerable; and NT, Near-threatened (based on Collar et al. 1994).

Vietnam holds three EBAs: the Annamese Lowlands in central Vietnam (with four restricted-range species), the Da Lat Plateau in the western highlands (with four species), and the lowland forests of what was formerly called Cochinchina (with two species). The Annamese Lowlands covers the lowland forest habitats of central Vietnam, supporting four species of endemic galliform, including three endemic and little known taxa of Lophura pheasant whose global ranges are entirely confined to this small area. Although five protected areas either exist or are planned for this area, none of the three species of endemic Lophura pheasant is known to occur within the boundaries of these sites.

\section{The Annamese Lowlands EBA}

Eight restricted-range species have been recorded in the Annamese Lowlands EBA (Table 1). The global ranges of four bird species (Annam Partridge Arborophila merlini, Imperial Pheasant Lophura imperialis, Vietnamese Pheasant and Edwards's Pheasant $L$. edwardsi) are confined to this EBA. All eight species inhabit evergreen forest and five species are only known from forest below $1,000 \mathrm{~m}$. The three Lophura species are only known from the level lowlands and are not known to occur on hill-slopes above $400 \mathrm{~m}$. Most of the remaining forest is on hill-slopes above this elevation, so the survival of these pheasants depends on the protection of the few remaining patches of suitable habitat. The three Lophura species are not known to occur in any existing or proposed protected area. The validity of two of the three Lophura taxa has recently been questioned (Anderson 1992) and a comprehensive conservation prescription for these species cannot be elaborated until the taxonomic question has been resolved. Two further species of Lophura pheasant are known from Vietnam, and altogether four of them are considered threatened (imperialis and edwardsi classified as Critical, hatinhensis as Endangered, and Siamese Fireback L. diardi Vulnerable: Collar et al. 1994). The three from the Annamese Lowlands are therefore clearly of major conservation concern. 
Evidence of congruence in endemism shown by other taxa occurring in this EBA is illustrated by the historical occurrence of Francois's leaf-monkey Semnopithecus francoisi and the unprecedented and remarkable discovery of two newly described species, Pseudoryx nghetinhensis and Megamuntiacus vuquangensis, which represent a new family and genus respectively (Do Tuoc et al. 1994 and Vu Van Dung et al. 1993). In addition, skeletal material from an unidentified deer Cervus sp. has also recently been obtained from $\mathrm{Ha}$ Tinh and Nghe An provinces which may represent another undescribed species.

Earlier work by BirdLife International led to the discovery of a forest area near Ke Go Lake in Ha Tinh province which supported a population of Vietnamese Pheasant L. hatinhensis and Imperial Pheasant L. imperialis (Robson et al. 1991). However, because of the degraded condition of this site and continuing human pressures, it was not clear whether or not it was the most appropriate target for the establishment of a protected area to conserve these species. It was also evident that the level of knowledge of these endemic Lophura pheasants was very poor, and that there was a need to understand more fully their basic habitat requirements before a comprehensive programme for their conservation could be developed. It was against this background that BirdLife International and the Species Survival Commission of IUCN, the World Conservation Union, resolved to undertake fieldwork jointly, in collaboration with the Ministry of Forestry, in an attempt to resolve these questions. This fieldwork was initiated in spring 1994 with surveys that focused on the northern part of the Annamese Lowlands, within the known range of Vietnamese and Imperial Pheasant. Scientific and English names of birds used in the text follow Sibley and Monroe (1990). The scientific and English names of mammals used in the text follow Corbet and Hill (1992).

\section{Status of Annamese Lowland Lophura pheasants}

Edwards's Pheasant Lophura edwardsi Discovered in 1895 near Hue (Oustalet 1898), this species was subsequently collected from at least eight localities from northern Quang Tri province south to northern Faifoo province (Delacour and Jabouille 1925, 1931). Delacour noted that it was uncommon in its restricted range (Delacour et al. 1928), whilst recent surveys within its known former range have failed to find it at all (Robson et al. 1990, Eames and Robson 1992), suggesting that it could be extinct in the wild (Nguyen $\mathrm{Cu}$ and Eames 1993). Although Delacour (1977) asserted that this species occurred up to $600 \mathrm{~m}$, noting that it was collected on the eastern slopes of the Annamatic chain (Delacour and Jabouille 1925), all the collecting localities were in flat forest on the coastal plain, and there is no good evidence to support Delacour's statement (Eames and Robson 1992). It is possible that this species could persist in small isolated valleys in southern Thua Thien-Hue and northern Quang Tri provinces, but all of the historical collecting localities have been deforested (Eames and Robson 1992).

Imperial Pheasant Lophura imperialis This is one of the least-known pheasants in the world, being known from three specimens. Two live birds were trapped in the vicinity of Dong Hoi (in present-day Quang Binh province) in 1923 
(Delacour and Jabouille 1931) and a immature male specimen was purchased from a hunter in 1990 that was said to have been obtained $12 \mathrm{~km}$ west of Cat Bin in Cam Xuyen district, Ha Tinh province (Robson et al. 1993). The latter specimen was reported to have been trapped in secondary lowland forest at 50$100 \mathrm{~m}$ altitude. Two Vietnamese Pheasants were reported to have been trapped in the same trap line. Evidence that these two species occur together in Vietnam is therefore strong, and, further south, Delacour and Jabouille (1931) reported that $L$. imperialis seemed to be found in the same areas as $L$. edwardsi, although they had previously stated (1925) that $L$. imperialis replaced $L$. edwardsi in the more northern part of Annam. The exact distribution and habitat requirements of these species remains unclear.

Vietnamese Pheasant Lophura hatinhensis The type-specimen of Lophura hatinhensis was collected from Son Tung (c. $\left.17^{\circ} 59^{\prime} \mathrm{N} 106^{\circ} 10^{\prime} \mathrm{E}\right), \mathrm{Ky}$ Son sub-district, Ky Anh district in Ha Tinh province (Rozendaal et al. 1991). Since this time, it has been reliably reported only from the nearby area of Ke Go Lake (south of the lake in Cam Xuyen district, Ha Tinh province) (Robson et al. 1993). Trappers in the Ke Go Lake area reported that this species occurred in level or gently sloping terrain, preferring forest close to streams. Birds observed by Rozendaal et al. (1991) in Hanoi Zoo were said to have come from Minh Hoa district of Quang Binh province (c. $\left.17^{\circ} 47^{\prime} \mathrm{N} 106^{\circ} 01^{\prime} \mathrm{E}\right)$, although there are doubts about the precise collection locality of these specimens, as it is also claimed that they were obtained from Ky Thuong or Ky Son markets in Ha Tinh province (Nguyen Cu and Eames 1993). Unconfirmed reports of all-dark pheasants from Cao Veu Anh Son district, Nghe An province (c. $18^{\circ} 50^{\prime} \mathrm{N} 105^{\circ} \mathrm{Oo}$ 'E), could also refer to this species (Rozendaal et al. 1991), although such reports should be treated with the utmost caution.

\section{The environmental setting}

Deforestation represents the single most important threat to the survival of these species. Although historically Vietnam was almost completely forested, the country has now lost more than $80 \%$ of its original forest cover. Only 10$12 \%$ of original closed tropical forest remains, of which less than $1 \%$ is in a pristine state, and the rate of forest loss was recently estimated to be 311,000 ha per year (Collins et al. 1991). Although forestry lands total 19 million ha or $58 \%$ of the country, only 9 million ha are actually forested (BAP Planning Team 1993). Statistics abound as to the extent of remaining forest lands, and close scrutiny is required to understand the situation fully: for example, it was recently shown that the forested area for the five provinces of the Annamese Lowlands were in the ranges $44.7-54.8 \%$ (Nghe Anh, Ha Tinh and Quang Binh), $30.1-42.2 \%$ (Quang Tri) and 60.7-71.9\% (Thua Thien-Hue) (Vu Tu Lap and Taillard 1994). However, data provided by the Forest Inventory and Planning Institute show that in the case of Ha Tinh, although $50 \%$ of the land area of the province may appear to be forested (Figure 1), the percentage forest cover on that $50 \%$ varied between $1 \%$ and $20 \%$ (BAP Planning Team 1993). It has further been shown that recent apparent increases of the forest area in some provinces are as a result of changing methods of classifying forest, which now includes 


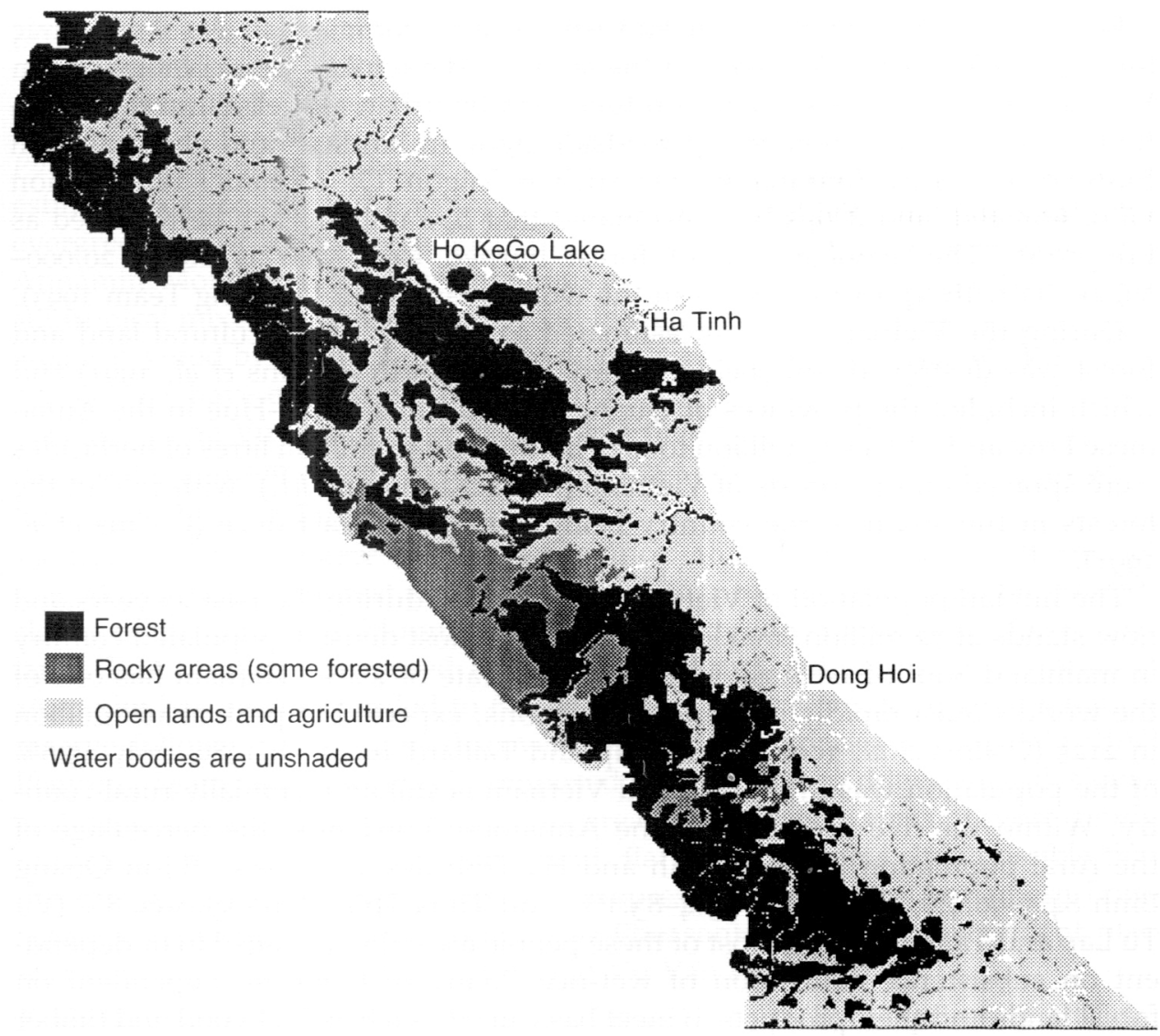

Figure 1. Forest cover in the Annamese Lowlands as mapped by FIPI. Based on 1993 satellite imagery and 1994 ground truthing.

early regeneration stages, new forest plantations and bamboo. The area covered by original forest and the proportion of forest that is classified as having good or medium tree cover is still decreasing. Furthermore, there is evidence that the quality of remaining forest is also decreasing (BAP Planning Team 1993).

There are several reasons for the loss of forest cover. These include logging, over-collection of fuelwood, forest fire and war damage, but perhaps the greatest loss of forest cover has been caused by clearance for agriculture, including the shifting cultivation practised by Kinh (ethnic Vietnamese) and tribal minorities (BAP Planning Team 1993).

Logging remains a major threat to natural forest although the areas legally under concession are greatly limited and many restrictions have recently been placed on the export of unsawn timber, felling of certain species, and logging in important watersheds. Forest law requires that felled forests are restored after logging, but this is rarely implemented. There is in addition a serious level of illegal logging, including the use of false stamps and timber smuggling, causing the degradation of 70,000 ha per year and actual forest loss of 30,000 ha per year (BAP Planning Team 1993). 
Fuelwood collection for both subsistence and commercial use is endemic throughout Vietnam. Estimates of the scale of this activity are unobtainable. In Vietnam, there is a dependency on fuelwood by urban as well as rural populations, and there is a flourishing roadside trade in kindling and charcoal from forested rural areas into major cities such as Saigon. Of Vietnam's nine million ha of forested land it has been estimated that five million may be regarded as fire-prone. The average area of forest burned each year is about 20,00030,000 ha with up to 100,000 ha in the worst years (BAP Planning Team 1993).

During the Vietnam War, an estimated $22,000 \mathrm{~km}^{2}$ of agricultural land and forest was destroyed, this being mainly in the south (Collins et al. 1991) and which included the provinces of Quang Tri and Thua Thien-Hue in the Annamese Lowlands. Over 13 million tons of bombs and 72 million litres of herbicides were sprayed on the forests of Vietnam (J. MacKinnon in litt.), with $12 \%$ of the forests in the south of the country being sprayed at least once (Collins et al. 1991).

The human population of Vietnam has doubled during the past 27 years and now stands at 72 million, making Vietnam the most densely populated country in mainland South-East Asia. With a growth rate of $2.4 \%$, Vietnam has one of the world's most rapidly growing populations, expected to peak at 168 million in 2125 (Collins et al. 1991, Vu Tu Lap and Taillard 1994). In 1989, only $25.6 \%$ of the population was urbanized and Vietnam is still an essentially rural country. Within the five provinces of the Annamese Lowlands, the percentage of the rural population in Nghe Anh and Ha Tinh lies at 91.5-95.3\%; in Quang Binh 84.5-90.4\%; Quang Tri 73.4-83.1\%, and Thua Thien-Hue 57.0-69.8\% (Vu Tu Lap and Taillard 1994). Most of these people are either engaged in or dependent on subsistence cultivation of wet-rice. Many of them are dependent on forest lands and their products to meet basic needs such as fuelwood and timber for construction.

\section{The protected-areas system in the Annamese Lowlands EBA}

The Ministry of Forestry is currently establishing a national protected-areas system. To date, six national parks, 28 nature reserves, five historical and cultural reserves and two unclassified areas have been designated, with an area totalling $10,945 \mathrm{~km}^{2}$ (Collins et al. 1991). Within the Annamese Lowlands EBA, one national park, two nature reserves and one cultural and historical site have been proposed.

Many of the areas selected have been degraded by war and logging, and are subject to agricultural encroachment, wood-cutting and hunting. Furthermore, in some cases insufficient attention was paid to selecting these areas on the basis of their biodiversity or levels of endemism. Habitats representative of all eight restricted-range bird species known from the Annamese Lowlands EBA have not yet been included in the protected-areas network. The three endemic Lophura species are not known from any currently designated protected area.

An attempt has recently been made to prioritize protected areas for development by ranking their biodiversity value, the scale of threat faced and the level of infrastructure development. Bach Ma National Park, Pu Mat and Vu Quang Nature Reserves, and Ke Go Lake were all allocated to the highest category (A) for their biodiversity value and flagged in urgent need of conservation action, 
given the levels of threat they face. Phong Nha Cultural and Historical Site was allocated B priority (BAP Planning Team 1993). A brief synopsis of each of these areas is given below.

$P u$ Mat Nature Reserve (Nghe Anh province: $18^{\circ} 50^{\prime} \mathrm{N} 104^{\circ} 45^{\prime} \mathrm{E}$ ), covering an estimated 93,400 ha, and encompassing the largest remaining area of primary evergreen forest in northern Vietnam, is located on the eastern slope of the Annamite Mountains. This mountainous area comprises lowland evergreen and subtropical mixed coniferous and broad-leaved forest. An estimated $95 \%$ of the area is covered by primary or slightly degraded habitats. Whilst some preliminary surveys have established the presence of several globally threatened mammals including Vu Quang ox Pseudoryx nghetinhensis, there is no published bird list and its representativeness of the Annamese Lowlands EBA remains undocumented (Anon. 1993a).

$V u$ Quang Nature Reserve (Ha Tinh province: $18^{\circ} 20^{\prime} \mathrm{N} 105^{\circ} 20^{\prime} \mathrm{E}$ ) is an area of logged and primary forest rising from $30 \mathrm{~m}$ to 2,000 $\mathrm{m}$ located on the eastern slopes of the Annamite Mountains at the western edge of the Annamese Lowlands EBA. Initially proposed as an historical and cultural site, the original 16,000 ha has been expanded to 60,000 ha and the area re-designated a nature reserve following the recent discovery of two new species of ungulate (BAP Planning Team 1993). Although composed largely of steep ridges and hill slopes and deeply incised valley bottoms, the area also supports areas of more gently undulating terrain including some broad, flat valley bottoms. It is possible that the site could support faunal elements representative of the Annamese Lowlands, such as Imperial and Vietnamese Pheasants. A draft management plan was completed in 1992 (MacKinnon and Vu Van Dung 1992).

$\mathrm{Ke}$ Go Lake ( $\mathrm{Ho} \mathrm{Ke} \mathrm{Go}$ ) (Ha Tinh province: $18^{\circ} \mathrm{O} 6^{\prime} \mathrm{N} 105^{\circ} 56^{\prime} \mathrm{E}$ ) comprises an artificial water body approximately $25 \mathrm{~km}$ in length and $5 \mathrm{~km}$ in breadth at its widest point. It has an average depth of $18 \mathrm{~m}$ and a capacity of approximately 400 million $\mathrm{m}^{3}$. The lake watershed covers 64,600 ha, of which cultivated land covers 24,000 ha, uncultivated land 21,000 ha, forest land 12,000 ha and the remaining 8,000 ha are wasteland (Anon. 1993b). Within the watershed of the lake, the area between Ky Thuong sub-district, Ky Anh and Ho Ke Go, Cam Xuyen was identified during surveys in 1988 as being a potentially important area for the globally threatened Vietnamese and Imperial Pheasants (Eames et al. 1989, Robson et al. 1991).

The terrain is generally level, but there are variations in altitude between c. 40-200 $\mathrm{m}$. The area is intersected by numerous streams and rivers. There are a few isolated low hills reaching a maximum height of c. $450 \mathrm{~m}$. Forest types in this area have been classified as Lowland Semi-Evergreen (MacKinnon and MacKinnon 1986) or Closed Broadleaved Tropical Evergreen Seasonal Lowland dominated by Dipterocarpaceae, Fabaceae, Meliaceae and Sapindaceae (CVRER 1985). Official commercial logging activities ceased in 1991 but widespread illegal logging persists. The area is classified as a Watershed Protection Forest and receives nominal protection under the law. It has been proposed as a nature reserve.

Recently, a German conservation NGO, Oro Verde, and the local provincial authorities launched a conservation project to protect 700 ha of primary and secondary lowland evergreen forest in Ky Thuong sub-district, Ky Anh district. 
The relevant district people's committees have jointly agreed to support a ban on logging, gold mining and hunting in the area. Signs have been posted at strategic points along the boundary of the area and local villagers employed to police the logging and hunting ban. The project has provided a number of small hydro-electric installations and assisted with agricultural extension in the form of providing high-yielding rice varieties, establishing a fruit-tree nursery and bee-keeping for those local communities who endorse the idea of the protected area.

Phong Nha Cultural and Historical Site (Quang Binh province: $17^{\circ} 25^{\prime} \mathrm{N} 106^{\circ}{ }_{15}^{\prime} \mathrm{E}$ ), encompassing 40,000 ha of lowland evergreen forest, much of it on limestone, was established to commemorate the North Vietnamese Army units which fought and took refuge in the area during the Vietnam War. The site protects spectacular karst scenery in the centre of the Annamese Lowlands EBA. Phong Nha is located close to Dong Hoi from where Imperial Pheasant was obtained: thus the forest could support a population of this enigmatic species.

Bach Ma National Park (Thua Thien-Hue: $16^{\circ} 05^{\prime} \mathrm{N} 107^{\circ} 43^{\circ} 53^{\prime} \mathrm{E}$ ) covers an area of $22,030 \mathrm{ha}$. The terrain is steep and mountainous with elevations ranging from sea-level to $1,448 \mathrm{~m}$. Floristically, the park comprises three forest types, lowland, transitional and lower montane (Casella et al. 1994). Within the park the forest of the level lowlands has been completely destroyed and forest formations remain only on hill slopes, which have in turn been subject to chemical defoliant spraying during the Vietnam War and to commercial logging, the latter ceasing only in 1989 .

The park was identified for survey by ICBP (now BirdLife International) in 1990 , as it is the only protected area within the historical range of Edwards's Pheasant. Faunal surveys were carried out in the park during 1990 and 1991, but no suitable habitat for Edwards's Pheasant was located (Robson et al. 1991, Eames and Robson 1992).

\section{Previous ornithological surveys in the Annamese Lowlands}

Fieldwork conducted by ICBP and BirdLife International since 1988 has identified new localities for Vietnamese Pheasant and led to the rediscovery of Imperial Pheasant, but failed to yield any information regarding Edwards's Pheasant (Eames et al. 1989, Robson et al. 1991, Eames and Robson 1992). A potentially suitable area for the conservation of Imperial and Vietnamese Pheasants was identified in Cam Xuyen district, which is located to the south-east of the Ke Go Lake in Ha Tinh province, during 1990 (Robson et al. 1991). This area was subject to a further survey in 1992 (Anon. 1993b). In 1989 and 1991 surveys for Edwards's Pheasant were undertaken at a number of sites in Thua Thien-Hue and Quang Tri provinces, including Bach Ma National Park.

While these surveys failed to yield any new information about the species (Eames and Robson 1992), they revealed that the Annamese Lowlands are perhaps the most seriously threatened ecosystem in Vietnam, as virtually all of the forest in the level lowlands has been converted to wet-rice cultivation and most of the low-lying hill country has been subject to widespread deforestation. The establishment of protected areas in the Annamese Lowlands EBA which 
adequately meet the needs of biodiversity conservation is therefore considered an urgent priority by BirdLife International and IUCN.

\section{Project aim and objectives}

The aim of the 1994 field surveys was to identify the most suitable area or areas within the present range of Vietnamese Pheasant and/or Imperial Pheasant, for proposal as a protected area.

With this aim in mind, fieldwork was carried out in the Annamese Lowland EBA with the following objectives: (1) to assess the conservation status of existing nature reserves; (2) to gather data on the habitat requirements of $L$. hatinhensis and $L$. imperialis, and assess the condition of habitat in areas where they occur; (3) to determine the types and level of threats to L. hatinhensis and L. imperialis; (4) to assess, briefly, the biological and sociological value of the area(s), particularly as it relates to the conservation of Lophura pheasants and other fauna representative of the Annamese Lowlands, and to assess the feasibility of success in gazetting a protected area; and (5) to obtain blood and tissue samples from $L$. hatinhensis and $L$. imperialis to facilitate determination of the taxonomic status of the three Lophura taxa presently recognized.

\section{Methods}

\section{Selection of survey sites}

Survey sites were selected by reference to Landsat TM 1990 images, 1:250,000 vegetation maps produced by the Forestry Inventory and Planning Institute of Ministry of Forestry (FIPI: see Figure 1) and reference to 1:50,000 topographical maps of central Vietnam. In addition, the ornithological literature was thoroughly reviewed. Once specific areas had been identified, discussions were held with provincial forest departments to determine the feasibility of surveying the areas, given the prevailing physical conditions.

Following site selection, five sites were surveyed at four different localities (Figure 2). Rapid reconnaissance surveys employing qualitative survey methodologies were employed at each site for periods ranging from one week to ten days. In addition to direct observation, non-lethal trapping techniques and interviews with local hunters were used to determine the presence or absence of restricted-range species. Using established techniques, blood and tissue samples were taken from three Vietnamese Pheasants so that their taxonomic affinities may be determined later using the latest DNA analysis techniques.

\section{General inventory work}

The fieldworker attempting to determine the composition of bird communities, and the relative abundance of species in tropical forests, faces numerous difficulties not generally encountered in temperate forests. Furthermore, survey and census procedures developed in temperate forests are often inadequate in tropical regions. The fieldworker in tropical forests is faced with a diverse avifauna, including many species which are seldom recorded because they are shy 


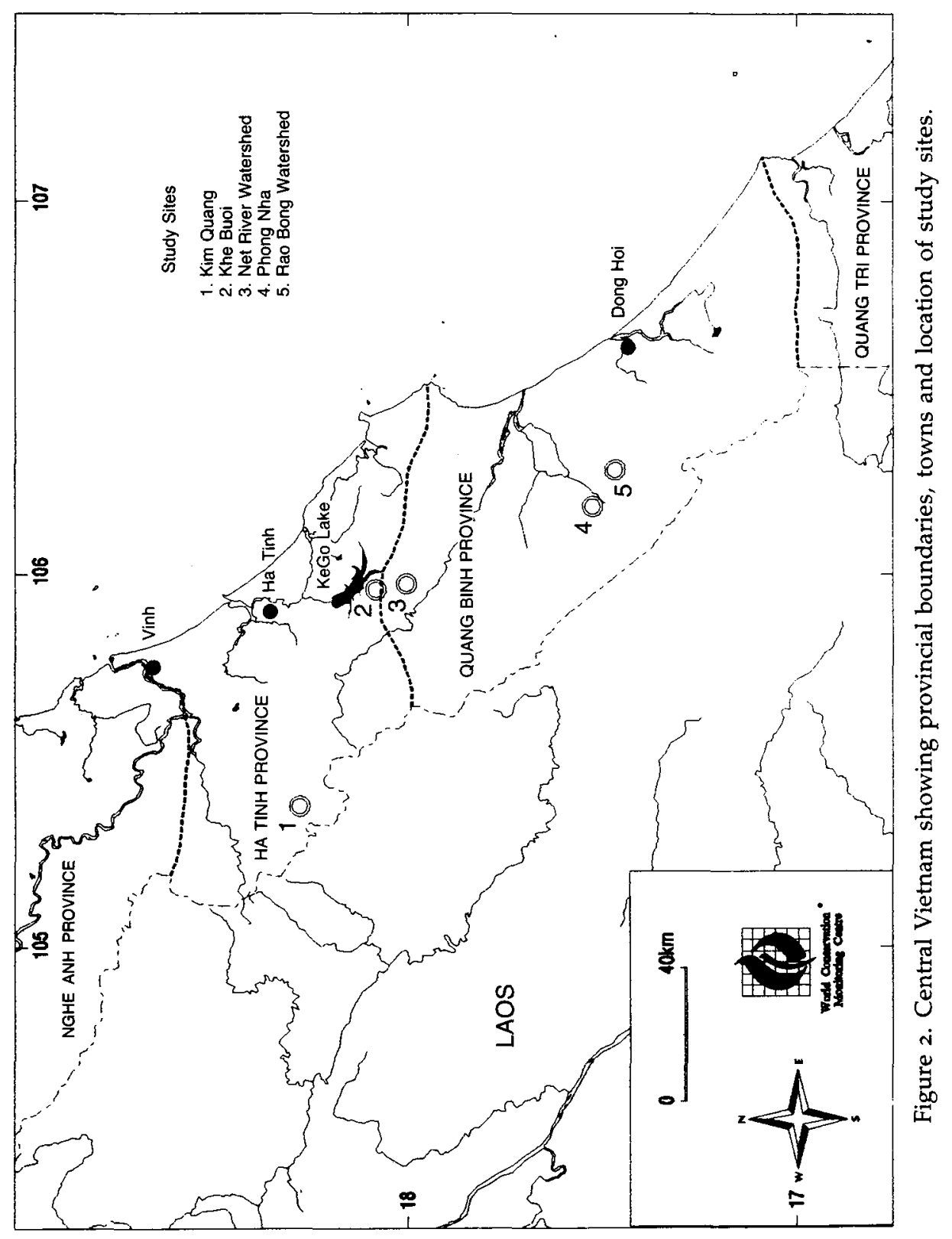


or occur at low density. Other behavioural traits, rare amongst temperate species (including permanent occupation of territories, decreased levels of singing, secretive habits, extensive overlap in home ranges, and nomadism), are common among tropical species. The significance of these problems to the fieldworker have been the subject of extensive reviews (Karr 1981, Verner 1985).

The importance of developing a methodology for use in conservation surveys using point counts, transect counts and square counts was recently reviewed by Bloch et al. (1991). Given the difficulties and frustrations of using quantitative methods for surveying birds in tropical forests it is perhaps not surprising that many researchers adopt non-systematic or non-quantitative methods (Safford and Duckworth 1988, Allport et al. 1989, Dutson and Branscombe 1990). However, species lists are most useful to the conservationist when they are standardized by effort and area sampled. They can provide information useful in three basic areas of interest: species richness, biogeography and frequency of occurrence (Verner 1985). When prioritizing forest areas for conservation based on species richness, it is important that the methods used are comparable to enable ranking which will reflect true differences between sites.

During the 1994 surveys, bird and mammal inventories were generated by walking forest trails and roads using binoculars and a tape-recorder, all bird and mammal species observed being identified whenever possible. In addition, signs of galliforms in the form of feeding scrapes, feathers and droppings were sought. King et al. (1975) give a detailed account of the typical diurnal cycle of bird activity in a tropical forest and how an observer may maximize opportunities for generating species lists by selecting habitats such as gullies, ridge-tops and fruiting trees where the chances of encountering a particular species would be considerably enhanced. Observers were active from dawn until late morning (c.11hoo) and again in the afternoon from c.14hoo until dusk. Whilst the period of activity could be standardized between observers, potential sources of bias included the varying levels of vision, hearing, skills, experience and effort of observers.

\section{Tape-recording and playback}

Virtually all forest birds are readily located by their vocalizations. Where possible, unknown calls were taped, and the bird lured into the open using playback techniques in order to identify the species.

\section{Interviews}

By interviewing experienced local hunters it was often possible to learn of the presence of a particular species and whether or not a given area was suitable for survey work. Photographs and illustrations depicting the relevant species or groups of species believed to occur in an area were shown to hunters who had no previous knowledge of the aims of the survey. Hunters were asked to describe preferred habitats and behaviour of individual species, and were encouraged to present feathers and skins of birds and mammals they had shot or trapped. 


\section{Trapping}

Many terrestrial forest bird species are shy and difficult to detect in the forest undergrowth, especially outside of the breeding season when the species concerned may not call. During short survey periods, such species are easily overlooked. It was decided therefore to employ experienced local hunters to set trap-lines of non-lethal snares designed to catch terrestrial birds. Made of twine composed of natural fibre, the nooses were fixed to a sapling under tension. The noose was set on the ground in a gap in an artificial line of brushwood. The snare was triggered by means of a pressure plate set beneath a few leaves in the gap. Once triggered, the sapling to which the snare was attached reverted to the vertical position, drawing the noose tightly around the tarsus of the bird. Once held, the trapped bird usually ceased to struggle after only a few minutes. Up to 50 snares were set in one trap-line which sometimes extended for $100 \mathrm{~m}$ across the forest floor, often along slopes where galliforms are believed to prefer to feed. Trap-lines were checked after the peak periods of activity in the morning and afternoon. Birds were released back into the general area from which they were trapped in an attempt to minimize stress.

\section{Collecting blood samples from birds}

Blood samples were taken from a wing vein using a method recommended by P. Arctander and J. Fjeldså (in litt.). Feathers were cleared by using a wet finger tip. The vein, then quite visible, was punctured using a single-use sterile syringe. The blood drops then appearing on the surface were sucked up using a syringe or capillary tube. Bleeding generally ceased after one or two drops had appeared at the surface. The blood sample was immediately decanted into a tube containing EDTA-buffer of $\mathrm{pH} 8.9$ (10\% EDTA, 1\% NaF, trace of thymol) and labelled. In addition to blood, a feather sample was also collected and stored in the buffer wherever possible, especially using feathers in pin.

\section{Results}

The results of the field surveys are presented below on a site-by-site basis. The results are described under five subtitles, describing topography, habitat and status of habitat, human exploitation of forest resources, the pheasant fauna present, and a brief description of other faunal elements, in particular, documenting the presence of restricted-range and globally threatened species (as defined in ICBP 1992 and Collar et al. 1994). Figure 2 shows the locality of these sites and Appendices 1 and 2 give lists of all bird and mammal species encountered at each.

\section{Kim Quang, Vu Quang Nature Reserve, Ha Tinh province}

Status of habitat The topography of the areas in which surveys were carried out varied from the broad, almost flat forested flood-plains of the major rivers (at c.30-40 $\mathrm{m}$ altitude) to very steep forested slopes. In some places, a second flat plain was found in adjacent valleys (at c. $50-60 \mathrm{~m}$ ). At the edges of these 
flat plains, the ground rose steeply, and in some instances $20 \mathrm{~m}$ cliffs bordered the valley bottoms. A few small stream beds, feeding the main river from the adjacent steep-sided valleys, crossed the valley bottom, but these contained little or no running water at the time of the surveys. Although the terrain was very steep on the sides of the main and in adjacent valleys, ridge-tops frequently contained areas that were flat and $10-15 \mathrm{~m}$ broad. The main rivers were 10$20 \mathrm{~m}$ wide, meandered considerably, and were characterized by fast-flowing sections interrupted by deeper pools. The stream beds were rocky, with many large boulders along the whole length of the river.

Tall, closed-canopy forest, characterized by large buttressed trees on the flatter river plains, dominated the areas in which most observations were made. Little cutting of large trees was evident in this area, although on some of the steeper slopes in valleys adjacent to the main river small numbers of large trees had been recently (and illegally) felled and were being sawn into planks. Trees reached some $40 \mathrm{~m}$ tall in flat areas close to the river, but, on the steep slopes, such trees were rare, although the forest was largely primary. In the flatter valley bottoms, the understorey largely comprised tree saplings, mixed with occasional palms, including rattan. On the steeper slopes and ridge-tops, many areas were dominated by an abundance of fan palms (probably Licuala sp.). Large strangling figs (Ficus sp.) were common in the valley bottom. Bamboo was generally rare, primarily occurring in the understorey at scattered localities on the slopes and ridge-tops, and nowhere dominating the vegetation. The leaf-litter in the valley bottoms remained damp during most of the survey period, but dried rapidly on the slopes and ridge-tops.

Closer to the village of Kim Quang, forest became increasingly degraded, with a more open canopy, few large trees and a denser understorey. The area closest to the village was largely dense scrub, with scattered taller trees. Little survey work was conducted in these areas because heavy human use, including hunting and trapping, reduced the possibility that these areas would support many pheasants.

Human activities Exploitation of forest resources is reported to be seasonal, with the most intensive use occurring in the dry season. Hence hunters interviewed in Kim Quang village reported that the main trapping and hunting season was October to February. Abandoned temporary camps were observed intermittently along the main rivers, suggesting that human activities had been intensive earlier in the year.

Hunters reported that approximately half of the 104 families of Kim Quang village (population c.400) had a hunter. Hunting is primarily focused on larger mammals, which still occur in the Vu Quang Nature Reserve and adjacent areas in sufficient numbers to satisfy hunters' needs. Deer are one of the prime targets of hunters, but hunters reported that any mammal encountered would be killed if possible. Hunting methods included the use of snares, using dogs to chase animals into rivers (where slaughtered by hand) and shooting, although guns were not reported to be widely available. According to villagers, only a few trappers from Kim Quang usually set snares for partridges and pheasants, this being attributed to the relatively small amount of meat available in comparison to larger, mammalian quarry. A few tail-feathers of Grey Peacock-pheasant 
Polyplectron bicalcaratum and of Crested Argus Rheinardia ocellata were seen in hunters' houses, and Silver Pheasant Lophura nycthemera and partridges were sometimes trapped. The only evidence that hornbills were hunted was the possession of the skull of a Great Hornbill Buceros bicornis by one of the villagers. However, numbers of hornbills are now so low in the area, and individuals are so shy and wary, that it is unlikely that much material evidence of their exploitation would be found.

Wood is the principal construction material in Kim Quang and in the villages along the route from Kim Quang to the coast, and the demand for hardwood timber for domestic purposes is presumably rather high. Logging activities are strictly illegal in the nature reserve, but local villagers interviewed claimed not to be aware where the borders of the protected area lie. Soldiers at the military border post, between Kim Quang village and the forested valley in the Vu Quang Nature Reserve, reported that logging activities had ceased. However, this was found to be untrue: selective cutting of larger trees on the slopes and ridge-tops was observed during our survey. Trees are felled using axes and sawn into planks which are later transported by domestic water buffalo. Judging by the number of fresh buffalo tracks observed on the trails leading from the forest to the village of Kim Quang, wood is being removed from the reserve on a daily basis. Whilst timber cutting appeared to be selective, the increasingly degraded state of forest towards Kim Quang suggested that the size class and variety of species cut by local people changes as preferred larger trees in accessible areas become scarcer. Hence, the closed-canopy forests that have been subject to recent low levels of exploitation are likely to be more heavily exploited in the near future.

At unspecified times of the year, villagers visit the primary forests in the survey areas to collect rattan. Rattan collectors usually spend several days in the forest, and during this time set snares for smaller mammals and pheasants to provide themselves with a source of fresh meat. Palm leaves are also collected by villagers for roofing material, and other non-forest timber products such as bark and other house-building materials are collected when needed. Bees' nests and honey are collected opportunistically. No evidence was obtained of resin collection or cutting trees for the extraction of resin.

Restricted-range species Crested Arguses were heard calling from the slopes and ridges in both valley systems, but the incidence of calling was low, involving only a few individuals. All calling birds appeared to be at altitudes above $300 \mathrm{~m}$. No other restricted-range species were recorded at this site.

Globally threatened species Apart from Crested Argus, the only globally threatened species recorded at this site were Blyth's Kingfisher Alcedo hercules and Red-collared Woodpecker Picus rabieri. In addition, several near-threatened species were present, as documented in Table 2. Green Peafowl Pavo muticus was recognized by local villagers, with a vague report that one had been shot in the district in 1972 .

Mammals The Vu Quang Nature Reserve is recognized as being of international importance following the recent discovery of two new mammal species, the $\mathrm{Vu}$ 
Table 2. Restricted-range and globally threatened bird species detected at study sites visited in 1994

\begin{tabular}{|c|c|c|c|c|c|c|}
\hline Species & Status & KQ & KB & NR & PN & RB \\
\hline \multicolumn{7}{|l|}{ Threatened Species } \\
\hline Arborophila charltonii Chestnut-necklaced & $\mathrm{V}$ & * & * & * & & * \\
\hline \multicolumn{7}{|l|}{$\begin{array}{l}\text { Partridge } \\
\text { Patrits }\end{array}$} \\
\hline Lophura hatinhensis Vietnamese Pheasant & $R, E$ & & * & * & & \\
\hline Lophura imperialis Imperial Pheasant & $\mathrm{R}, \mathrm{C}$ & & ? & $?$ & & \\
\hline Lophura diardi Siamese Fireback & $\mathrm{V}$ & & ? & * & * & \\
\hline Rheinardia ocellata Crested Argu & $\mathrm{R}, \mathrm{V}$ & * & $*$ & * & & * \\
\hline Alcedo hercules Blyth's Kingfisher & V & * & * & * & & \\
\hline Picus rabieri Red-collared Woodpecker & $\mathrm{V}$ & $*$ & * & * & * & * \\
\hline Stachyris herberti Sooty Babbler & $\mathrm{R}, \mathrm{V}$ & & & * & & \\
\hline Jabouilleia danjoui Short-tailed Scimitar-babbler & $\mathrm{R}, \mathrm{V}$ & ? & $(*)$ & * & & * \\
\hline Paradoxornis davidianus Short-tailed Parrotbill & $\mathrm{T}, \mathrm{V}$ & & $*$ & & & \\
\hline \multicolumn{7}{|l|}{ Near-threatened Species } \\
\hline Carpococcyx renauldi Coral-billed & & * & * & * & & \\
\hline \multicolumn{7}{|l|}{ Ground-Cuckoo } \\
\hline Anorrhinus tickelli Brown Hornbill & & * & * & * & * & * \\
\hline Pitta soror Blue-rumped Pitta & & * & * & * & * & * \\
\hline Pitta elliotii Bar-bellied Pitta & & * & * & * & * & * \\
\hline Macronous kelleyi Grey-faced Tit-babbler & & $\left({ }^{*}\right)$ & * & * & & \\
\hline Urocissa whiteheadi White-winged Magpie & & * & $(*)$ & * & $\left({ }^{*}\right)$ & $\left({ }^{*}\right)$ \\
\hline Cissa hypoleuca Yellow-breasted Magpie & & * & $(*)$ & * & $*$ & \\
\hline
\end{tabular}

Status: R, Restricted-range species; Threatened species classified as follows: C, Critical; E, Endangered; V, Vulnerable (based on Collar et al. 1994). Study sites: KQ, Kim Quang; KB, Khe Buoi; NR, Net River; PN, Phuong Nha; RB, Rao Bong watershed. *, present; $\left({ }^{*}\right)$, present but rare; $?$, presence uncertain.

Quang ox and giant muntjac. No evidence was obtained that these species occur in the valley bottoms investigated during this study, and it appears that at least the former is confined to forest at higher altitude. Mammals observed during the course of this study included red-shanked douc langur Pygathrix nemaeus, crested gibbon Hylobates gabriellae and Owston's banded civet Hemigalus owstoni (a young animal trapped and collected for IEBR). A full list of mammals recorded is provided in Appendix 2.

\section{Khe Buoi, Ke Go Lake, Cam Xuyen district, Ha Tinh province}

Status of habitat Forest along the southern border of Ke Go Lake and along the various streams that feed into the lake has been subjected to heavy use by local people. As a consequence, the area was found to consist of a mosaic of habitat types, dominated by secondary growth. Many of the low-lying areas and some of the very steep slopes were covered with tall, dense bamboo. Some areas close to the lake had been so seriously degraded that they had been converted to Imperata grassland. Small patches of evergreen vegetation, typically with small trees and a mixed understorey of saplings, bamboo and small palms, were also found, particularly along the edges of streams. Tall forest, with a more or less closed canopy, was largely restricted to the upper slopes and ridge-tops of surrounding hills, and to valley systems draining away from Ke Go Lake. Soils on the ridge-tops were stony in places, and in such areas fan palms dominated the understorey. 
Human activities Hunting and fishing were reported to be intensive in the area bordering Ke Go Lake, although few hunters were observed, suggesting that this is a seasonal activity. Most hunters are opportunistic and during the surveys were probably working on their land, since this was the time of rice harvest. The carcass of an unidentified deer that had been shot was the only evidence that hunting was occurring. Fish bombing was heard daily in the streams and rivers feeding the lake, but the absence of fishermen on the lake itself suggested that the fish resource may have been overexploited or that there are too few fish to justify exploitation. No large fish was observed in the streams, although good populations of small fish were evident. Numerous old camps and trails were found in the forest. The occupants of these camps, who were evidently woodcutters and rattan collectors, were reported to set snares to trap mammals and gamebirds for food. Hunting expeditions in search of deer and wild boar Sus scrofa frequently visit the areas of forest bordering the lake, particularly during the dry season and during Tet (the Vietnamese New Year). Smaller mammals, such as squirrels, are also shot if the opportunity arises.

Hunters reported that they trapped live pheasants for sale to dealers in $\mathrm{Ha}$ Tinh. During Tet, a number of pheasants fitting the description of Vietnamese Pheasant had been trapped in areas adjacent to the lake. In the provincial capital, Ha Tinh, an adult male and immature male Vietnamese Pheasant were observed in captivity at the army border post headquarters. The officer in charge believed that these birds, and four others that had been purchased but had subsequently died, had originated in the Vu Quang area. However, investigations and interviews in $\mathrm{Ha}$ Tinh, and at the border post at Kim Quang, indicated that these birds had almost certainly originated from the Ke Go Lake area, and perhaps included the birds reported trapped above. A wildlife trader in $\mathrm{Ha}$ Tinh reported that he occasionally sold live pheasants, including Vietnamese Pheasant, that mostly originated in the forests around Ke Go Lake. At the time of our visit, however, the only bird in his possession was a male Red Junglefowl Gallus gallus.

Logging activities have been intensive around the Ke Go Lake and have led to the major habitat changes documented above. This activity is continuing throughout the area, although it appears to be a seasonal activity that is carried out by farmers during periods when there is little work to occupy them on their land. Commercial selective logging activities, by the provincial Forest Department, may have occurred in the past, but there was no evidence that this continues in the Khe Buoi area.

An interview was conducted with staff of the provincial office of the Forest Department, in Ky Anh. They reported that their department had a logging plan that involved cutting a minimum of $1,000 \mathrm{~m}^{3}$ of timber per year until the year 2000. This figure is derived from a directive issued by the Ministry of Forestry, Hanoi, and is not based on any assessment of the volume of timber left in the province. Present logging activities are centred in the Ky Thuong and Ky Son districts, where there were estimated to be 7,642 ha of land under the jurisdiction of the Ministry of Forestry. Within this area, 1,196 ha were classified as "good forest" (presumably closed canopy), and 2,242 ha as "less good forest" (presumably secondary). Both these areas were classified as "protection forest", which were to be logged and then protected. A further 3,069 ha had already 
been deforested, but plans had been drawn up for a reforestation scheme. In 1994, a total area of 500 ha had been reforested in Ha Tinh province, at a cost of 400 million dong (c.US\$36,500, or c. $\$ 70$ per ha). A plan exists to reforest a further 1,700 ha by the year 2000. At the time of this project, only to ha of forest had been reforested in the Ky Thuong district, although some nurseries had been established with Casuarina and other (unspecified) species.

In addition to timber, rural people visit the forests on the south side of Ke Go Lake to collect non-forest timber products, notably rattan, and firewood. People regularly cross the lake by boat from the villages situated in the agricultural areas on the north side of the lake.

Restricted-range species No Vietnamese Pheasants were observed, but a freshly shed individual breast-feather of the male of this species was found. A second feather that was found was compared with those of specimens of both male Edwards's Pheasant and Imperial Pheasant in the British Museum. This feather was identified as a tertial from the left wing, and most closely matched that of male Imperial Pheasant. However, since no specimens of Vietnamese Pheasant were available for comparison, it is not possible to be certain about the identification. Both feathers were on trails, one in the shady understorey of tree saplings in low undulating terrain in an area dominated by bamboo and regularly dissected by streams, the other in degraded forest along a stream.

Observations were made of a single male Crested Argus in closed-canopy forest on a hill-top, and this species was regularly heard at the site in this habitat, on the ridge-tops and hills. Two other restricted-range species were observed, Grey-faced Tit-babbler Macronous kelleyi and Short-tailed Scimitarbabbler Jabouilleia danjoui, but both appeared to be rare, and were observed only in the taller, selectively logged forest outside of the Ke Go Lake catchment. None was recorded in the more degraded habitats surveyed in the Ke Go Lake catchment.

Globally threatened species Three Chestnut-necklaced Partridges Arborophila charltonii were trapped using snares set in mixed logged forest and bamboo, but no other globally threatened or restricted-range galliforms were caught. Short-tailed Parrotbill Paradoxornis davidianus was observed once in an area of bamboo. Other globally threatened bird species that were recorded were Blyth's Kingfisher, present along forested streams feeding $\mathrm{Ke}$ Go Lake, and Redcollared Woodpecker, which was relatively common. Near-threatened species recorded are listed in Table 2.

Mammals Few signs of mammals other than deer were obtained in the area visited in the catchment of Ke Go Lake. A full list of mammals recorded is provided in Appendix 2.

\section{Net River watershed, Quang Binh province}

Status of habitat The vegetation of the northern watershed of the Net River, between the border with $\mathrm{Ha}$ Tinh province and the main Net River, was a mosaic of primary and selectively logged forest, with a few more seriously 
degraded areas. The topography was varied, with a relatively flat area adjacent to the provincial boundary dissected by hills and meandering rivers draining into the Khe Net River. Surrounding areas consisted of numerous steep-sided river valleys and narrow ridge-tops. Most of these ridge-tops were covered in tall forest, with a more or less closed canopy. Large trees had been selectively logged in many areas but, despite this, much of the forest retained its primary character. Degraded areas were usually on steeper slopes, and often dominated by tall bamboo. The degree of logging and the incidence of gaps where trees had been cut also varied, with the highest intensity observed being in the region nearest the provincial border. Most of the forest in the flatter areas draining into the Khe Net River had been logged in the past, and the area was dominated by regenerating secondary forest with few tall trees, although some reached an estimated height of $20 \mathrm{~m}$. A higher proportion of taller trees occurred on the ridge-tops, frequently exceeding $25 \mathrm{~m}$ in height.

The understorey was as varied as the topography. The soil on some ridge-tops and steeper slopes was stony, and these areas were frequently dominated by fan palms. In other areas, including the ridge-tops close to the provincial border and surrounding the northern part of the Khe Net watershed, richer soils supported a luxuriant damp understorey of mixed saplings and occasional small palms and rattans. Areas dominated by bamboo were rare, primarily occurring in areas where the tree canopy had been opened by tree falls.

Human activities Human pressure on the forests bordering the provinces of $\mathrm{Ha}$ Tinh and Quang Binh has been intensive. At the time of the surveys most activities, notably logging, appeared to be occurring in Quang Binh province, although the people involved in these activities were from the Ky Anh district of Ha Tinh province.

Logging was the single most important activity identified during the survey in the Net River watershed. A logging road was found which ended approximately at the border with Quang Binh province, on the Ha Tinh side. This road was used by lorries collecting timber several times a week. It was not clear how much of this timber was being collected by the provincial logging enterprise. Timber collected for transportation on the trucks appeared to originate from the Ha Tinh border area, including some areas in Quang Binh province. This timber was in the form of large planks that had been extracted by domestic water buffalo. The principal logging activity, however, was carried out by groups of men who were following a system of trails emanating from the end of the road and passing into Quang Binh province. Our observations showed that these men were working up to several kilometres from the Ha Tinh border, and some were reported to work in the forests adjacent to the Net River, some $5 \mathrm{~km}$ from the border. Groups of men passed the survey field camp daily, and it was estimated that several hundred men were involved in these illegal logging activities during the week based at the camp. Timber was sawn into large planks at the site of tree felling, and the timber carried out as individual planks, along the trails in the Net River watershed (inside Quang Binh province) and out through the logging road towards Ky Anh.

Rattan collectors were observed in the forests bordering the two provinces, but this was reported to be a less important time for rattan collecting than at drier times of the year. Another major activity appeared to be the extraction 
of oils from dead trees, reportedly those in the family Lauraceae, including Cinnamomum tarthoxylum and other members of this genus. People conducting this activity were unclear as to the use or final destination of the oil that they were collecting, although it is apparently used in the manufacture of insecticides and a domestic cola drink. The collecting process involved setting up a metal cauldron and furnace next to a stream in the forest. Oil-rich wood pulp was boiled in the cauldron, using trees cut locally, and oils were collected when they condensed in a metal collecting flask in the stream. The men would stay about one month at the site, during which time the furnace was fed timber continuously. This timber was cut locally, and consisted principally of small- to medium-size trees. At the time of the surveys, this activity had been in operation only a few days, but the immediate vicinity of the collecting apparatus and camp had been completely cleared of trees. It was estimated that 10-20 trees were felled per day to feed the furnace. During the course of surveys, several other sites where oil extraction camps had been set up were observed in the forest, and it was reported that many men engage in this activity at some times of year. This activity is therefore probably a very significant factor in degradation of forest close to rivers and streams.

As at other sites visited, hunting was primarily conducted in an opportunistic manner at the time of the visit, with rattan collectors and loggers setting snares for wildlife, including pheasants. Several old snare trap-lines, and one in use, were observed in the forest. A crab-eating mongoose Herpestes urva was caught in one such trap-line. Fifty-five snares were set by the survey team in an attempt to catch Vietnamese Pheasants (for blood samples). During one week, one Vietnamese Pheasant, two Emerald Doves Chalcophaps indica, one Coral-billed Ground-cuckoo Carpococcyx renauldi, four partridges and three pittas were trapped in these snares, demonstrating their effectiveness for capturing terrestrial bird species.

Restricted-range species Despite evidence that woodcutters, rattan collectors and other hunters set snares in the Net River watershed and adjacent forests in Ha Tinh province, this area supported good numbers of pheasants. A healthy population of Vietnamese Pheasants was found in the watershed of the Khe Net River (Quang Binh province). The presence of Imperial Pheasant was not confirmed, although it was from this vicinity that a specimen was collected in February 1990 (Robson et al. 1993). Vietnamese Pheasants were observed by members of the survey team on six out of seven days.

A minimum of 2 or 3 adult male Vietnamese Pheasants, one adult female, one subadult male and 4 or 5 juveniles (including four together) were observed. Hence at least eight birds, and possibly more than ten, were observed during the week of fieldwork at this site. Details of these sightings, including observations of habitat use, are provided in the following section. One juvenile was caught in a snare, examined and released after taking blood samples. Appendix 3 provides biometrical data for this individual and information on bare part coloration and moult.

Habitat use by Vietnamese Pheasants in the Net River watershed All observations of Vietnamese Pheasant, except for that of one male, were made in a relatively small area, principally on ridge-tops and adjacent steep slopes, at an altitude 
of c.200-300 $\mathrm{m}$. The size of this area was no more than $1 \mathrm{~km}^{2}$. It was not possible to ascertain the amount of suitable habitat within this area, or to confirm whether or not these birds were evenly distributed throughout the forests. However, whilst most of the observations of pheasants were made on the main ridge-tops and on slopes close to these tops, none was seen during the many hours of sitting in valleys and waiting for pheasants to pass. This suggests that ridge-tops and the immediate slopes were preferred, rather than the adjacent valleys where vegetation in the understorey was noticeably sparse, with many areas almost devoid of cover.

The birds inhabited areas where the understorey was dominated by saplings and occasional palms, in closed-canopy forest where relatively recent selective logging had created frequent small clearings. At one site, a pair were observed on a steep slope $\left(45^{\circ}\right)$ with a westerly aspect. The ground here was sparsely covered in leaf-litter, with perhaps 50\% of the ground visible. At this site undergrowth was sparse with uninterrupted visibility for $20 \mathrm{~m}$. Rattans and palmate palms were virtually absent from the undergrowth. Large trees were absent, the average DBH being less than $10 \mathrm{~cm}$. Canopy height was 15-20 $\mathrm{m}$ with $90 \%$ canopy cover. A solitary male was observed c.1.5 km from the area in which other observations of the species were made. This individual was observed on a steep slope at the edge of an area dominated by bamboo, bordering an understorey of saplings, scattered rattans and fairly tall trees providing a more or less closed canopy. Although there was no evidence of recent tree-felling in the area, the forest on this ridge had been logged in the past with the consequence that the forest canopy was rather patchy.

Globally threatened species The Net River watershed was rich in restricted-range and threatened bird species. Compared to other sites, both Short-tailed Scimitarbabbler and Red-collared Woodpecker were common. Local people reported Siamese Fireback, although the area in which they were known to occur was closer to Cat Bin, in relatively flat, degraded forest. As at other sites, Crested Argus was heard calling only on hill- and ridge-tops, apparently in closedcanopy forest. A complete list of restricted-range and threatened bird species observed at this site is provided in Table 2.

Mammals Few mammals were directly observed, with the exception of crabeating mongoose, which was observed on several occasions, and pigs, which appeared to be relatively common. Indian muntjac Muntiacus muntjac were heard calling daily, and an unknown call of a deer (perhaps giant muntjac) was heard. Several gibbons were heard on occasion. Locals reported that sambar deer Cervus unicolor and bears were also present.

\section{Phong Nha Cultural and Historical Site, Quang Binh province}

Status of habitat Forests had been severely degraded in the most accessible parts of the limestone hills and outcrops that form the Phong Nha Cultural and Historical Site, despite the difficulties associated with extracting timber from such inhospitable terrain. Hence, little forest remained in the flat valley bottoms along the road towards the Laos border (route 20), and much of the forest on 
steep limestone slopes along this route had been selectively logged. Some areas along the highway had been converted to grassland and scrub. Nevertheless, one series of contiguous flat valleys, bordered by sheer or very steep limestone cliffs and slopes $100-150 \mathrm{~m}$ high, was discovered where logging activities had been relatively minor despite heavy use for other purposes (see below).

Two of these valleys were very narrow, being no more than $60 \mathrm{~m}$ wide and 150-200 $\mathrm{m}$ long and bordered by sheer cliffs, whilst the largest area was more like a plain between limestone outcrops, being some $1.5 \mathrm{~km}$ long and up to c. $500 \mathrm{~m}$ wide. In the largest flat area, forest was confined to the edges, in a band some 50-200 $\mathrm{m}$ wide. Large numbers of vines and creepers were present and the forest understorey was very open when compared to typical forest in the region. In some places, especially along a small river flowing across this valley, large bamboo dominated the vegetation, whilst small rattans were predominant in another area. The central area of the valley bottom was grassland with scattered tall trees.

Between these flat areas, and in adjacent valley systems, the terrain comprised slopes of jagged limestone rocks and outcrops of various gradients. Exposed soil and a good leaf-litter were present throughout the area, although on some slopes the area of exposed rock was far greater than that of patches of soil. In contrast, rocks were virtually absent from the flat valley bottoms. Within this general area the forest was largely primary, with many large buttress trees up to c. $25 \mathrm{~m}$ tall in the flat valley bottoms, and slightly smaller trees on the surrounding limestone slopes. An abundance of lianas and vines characterized the vegetation throughout the limestone region, growing over the rocky slopes and cliffs as well as the vegetation. In most areas the forest canopy was closed, only being broken where trees had been cut, or in the rare places where trees had fallen naturally.

Human activities There was little evidence of hunting in the limestone hills of Phong Nha at the time of this survey, although trapping of mammals is said to occur, particularly in the larger flat plain. In peripheral areas, in the valleys at the edge of the limestone massif, and on the slopes of adjacent non-limestone valleys along the road to Laos, hunting is more intensive. Hunters in the large village at the edge of the reserve, Son Trach, had the horns of both Indian muntjac and giant muntjac in their houses, as well as a single Wreathed Hornbill Aceros undulatus skull (of indeterminate age) and the feathers from several species of pheasant. It could not be determined whether or not these trophies were derived from hunting within the limestone hills or the adjacent forests such as those of the Rao Bong watershed. Closer to the limestone hills, one trapper had the feathers of Silver Pheasant, Siamese Fireback, Red Junglefowl, Grey Peacock-pheasant and Crested Argus. These had probably all been snared in the valleys adjacent to the limestone, although the hunter reported that he sometimes snared small animals including pheasants in the valleys within the limestone.

As mentioned above, logging had been intensive in the areas along the highway, regardless of slope. The only area where primary forest was found was on and in the limestone hills to the north of the highway. Even here, however, some logging activity had taken place. Large trees of indeterminate species had 
been selectively felled, mostly trees growing on the upper ridges and slopes in jagged limestone terrain. These had been sawn into small planks which were carried to the larger valley bottom before removal by domestic water buffalo to the road.

Within the limestone area, large numbers of local people were encountered who had been collecting bamboo shoots for food from within the large flat valley bottom, where groves of large bamboo were common along the river. This is reported to be a seasonal activity, the collectors camping in the area for a short period in which they may conceivably hunt, although no evidence for this was obtained. Evidence of rattan collecting was also observed but the intensity of this activity was not determined. A final activity that is worthy of note is scrap-metal dealing. Large numbers of villagers participate in this activity, which involves digging up the remains of bombs and other metal derived from the Vietnam War and selling it to scrap-metal traders. This rather dangerous occupation is assisted by the use of metal detectors. Digging up old bombs and the remains of military equipment is often very destructive, since the holes dug may be very deep and large, and are never filled in. People involved in this activity frequently camp in the forest and may then hunt wildlife for subsistence and collect other forest products, such as honey, opportunistically.

Restricted-range species No restricted-range pheasants were observed. However, one of the most important ornithological discoveries in Vietnam in recent times was made in Phong Nha during the course of this survey: a population of Sooty Babbler Stachyris herberti was discovered within the limestone valleys. This enigmatic species, previously known only from five specimens collected in Laos in 1920 (Baker 1920, 1921, Williamson 1945), was found to be relatively common in areas where primary forest occurred on steep limestone. New information on its habitat requirements and ecology were collected.

Globally threatened species Of the globally threatened species found in the Annamese Lowlands, only two (apart from Sooty Babbler) were observed in Phong Nha. Of these, only Red-collared Woodpecker was observed in forest on limestone. The other, Siamese Fireback, occurred in the area, although it was not observed in the limestone areas and may not have occurred in this habitat. This was the only site visited where Crested Argus and Chestnut-necklaced Partridge were not recorded. A number of near-threatened species were recorded, and these are listed in Table 2.

Mammals A second zoological discovery of significance was the sighting of Hatinh leaf-monkeys Semnopithecus francoisi hatinhensis. Prior to this survey, the geographical range of Hatinh leaf-monkey was undocumented. Whilst only one group was observed, sleeping every night on tall, exposed limestone cliffs above the forest, local people clearly recognized this taxon and provided anecdotal evidence that it is widely distributed throughout the area.

Mammals observed included a group of bear macaques Macaca arctoides, whilst local people reported the presence of gibbons. A specimen of Tamiops squirrel was collected for identification. No Tamiops has been documented in this part of Vietnam (Corbet and Hill 1992), although the form at Phong Nha was 
common; it is conceivable that the specimen collected may represent an undescribed taxon.

\section{Truong Son village and the Rao Bong watershed, Quang Binh province}

Status of habitat The Rao Bong watershed (to the east, north and south of the village of Truong Son in the vicinity of Dong Lai), an area to the south of Route $15 \mathrm{~A}$ on the periphery of Phong Nha Cultural and Historical Site, was under logging concession at the time of the surveys, and active selective logging using chainsaws was taking place. Although little time was spent in the active part of the concession area, observations suggested that even relatively small trees were being felled, including those along major rivers. Such practices have serious consequences for the recovery of the forest and for water quality and wildlife.

Although the survey was brief (four days), it was clear that the majority of the forest in the vicinity, including some of the area marked as closed-canopy forest on FIPI (1994) vegetation maps, had already been logged at least once. Vegetation on many of the steep sides of the valleys leading to the village had been cleared for agriculture. The main crops were wet-rice, bananas and cassava. Old logging roads led into these valleys, and the majority of tall trees had been removed from areas that remained forested, so that a rather patchy mosaic, mostly composed of regenerating secondary forest and secondary growth, dominated the landscape. On some of the slopes, fires had caused extensive damage and modification to the vegetation.

Closed-canopy forest was confined to ridge-tops and adjacent higher parts of valleys. However, even in these areas, frequent patches cleared by loggers were encountered and these had often been colonized by bamboo. The understorey on ridge-tops was often dominated by fan palms, as at other sites, but below the ridge-tops the understorey tended to be dominated by saplings and other small palms. Bomb craters were also commonly observed in some areas, particularly closer to the road to Laos and along the ridge-tops that were used by Vietnamese troops during the Vietnam War, providing evidence that much of the observed disturbance to the forests had probably started some 20-25 years ago.

Human activities Local people claimed that they did not hunt for pheasants regularly, since there was still sufficient large game to satisfy their needs. However, snare trap-lines were found in several places, some several kilometres from the village in areas where loggers had built temporary camps, and snares set by the project were stolen. Hence it appears that hunting pressure on small animals and larger species of terrestrial bird is probably relatively high. Despite assertions that good populations of larger mammals persisted in the area, little corroborating evidence was obtained. Feathers of Crested Argus were observed in several houses, although these could have been picked up in the forest rather than plucked from birds that had been trapped for food.

It was the impression of members of the survey team that past hunting pressures had been intense, this explaining the low numbers of pheasants and mammals detected. One hunter had recently shot a Great Hornbill for its tail 
feathers, which had been bound together to make a brush. The bird had been shot some $4^{\circ} \mathrm{km}$ away, near the border with Laos, and the hunter noted that this was now a very rare bird in the Rao Bong watershed. This not only points to high past levels of hunting, but also clearly demonstrates the low value attached to wildlife by most rural people: the feather duster could easily have been made from the feathers of a chicken.

Logging was the single most prevalent activity in the forests of the Rao Bong watershed at the time of the surveys. Not only was commercial logging taking place in the river valleys to the west of the village, but groups of local people were cutting trees on a daily basis and dragging timber from all adjacent areas where saleable timber was present, with the assistance of domestic buffalo, to the main road, using a well-worn trail that led towards the Phong Nha Cultural and Historical Site guard station. The whole area was dissected by deeply eroded, narrow tracks caused by the dragging of logs down steep slopes, providing evidence that logging activities were intensive.

The collection of rattan and palm leaves, as well as other forest products for the building of houses, is evidently a major activity of people from the village of Truong Son, although these activities were not observed during the 1994 visit. The collection of metal from bombs and other military debris is another activity that occurs in the watershed.

Restricted-range species Small numbers of Crested Argus were heard calling from ridge-tops and slopes throughout the area, but were not observed. Other restricted-range species were not found.

Globally threatened species Little evidence was obtained that the area had important populations of threatened birds. Short-tailed Scimitar-babbler was present but uncommon, whilst small numbers of Red-collared Woodpecker were observed. Locals reported trapping and observing Siamese Fireback. Table 2 documents other near-threatened species that were present at this site.

Mammals Only one primate species, an unidentified macaque, was observed, and little evidence of the presence of other larger mammals was obtained. Deer prints, probably of sambar, were seen in only one area.

\section{Discussion}

\section{Protected-area establishment for Vietnamese Pheasant populations}

Although there are some 89 protected areas in Vietnam (WCMC unpublished data, 1994), none of the three endemic Lophura species is known to occur in any of them (Nguyen $\mathrm{Cu}$ and Eames 1993). There is therefore an urgent need to establish a protected area in the Annamese Lowlands that safeguards populations of these species and other sympatric restricted-range and threatened species.

Apart from study sites visited during the course of the present surveys, there are no large blocks of forest within the known range of Vietnamese Pheasant that are likely to have viable populations of this species. A clear finding of 
this project is, therefore, that the forest block that incorporates the Net River watershed and Ke Go Lake watershed is the most appropriate area to propose as a reserve for the protection of Vietnamese Pheasant. This was the only area in which the species was found. It is also the only area from which Imperial Pheasant is currently known, although there is the possibility that this bird also occurs in forests in the south of Quang Binh province. Further surveys are required to define the status and geographical distribution of this species.

Within this area, which encompasses some c. $250 \mathrm{~km}^{2}$ of forest, priority can be given to the Net River watershed, in Quang Binh province. It is only in this area that Vietnamese Pheasant is known to be common. Whilst feathers and reports from hunters indicate its presence in the Ke Go Lake watershed, no ornithologists have ever observed the species in that area, despite hundreds of man-hours of observation over a period of several years. In contrast, it was seen daily, with a minimum of eight individuals involved, during the week of surveys conducted in the Net River watershed. The condition of forest in the Net River watershed is also superior to that around the Ke Go Lake watershed, with extensive areas of closed-canopy and selectively logged forest containing many of the elements of primary formations. In contrast, many areas in the Ke Go Lake watershed have been logged unsustainably, resulting in large areas of seriously degraded land, some already converted to grassland and others to pure stands of bamboo.

The status of Imperial Pheasant in the Net River/Ke Go Lake catchments has yet to be determined, although its presence is confirmed by a skin. The specimen collected in 1990 was said to have come from $12 \mathrm{~km}$ west of Cat Bin in Cam Xuyen district, Ha Tinh province (Robson et al. 1993): this area is probably on the edge of, or within, the Net River catchment.

Whilst a block that included the best forests in the Net River catchment and in the area between this catchment and Ke Go Lake would seem to be the most appropriate choice (based on biological considerations) for proposal as a protected area (as Special-Use Forest) development, political considerations dictate otherwise. The Net River catchment lies within Quang Binh province, with the watershed border effectively forming the border with $\mathrm{Ha}$ Tinh province, within which the Ke Go Lake and its catchment is located. Whilst the possibility of a trans-provincial protected area should be investigated, past experience has indicated that more rapid agreement over protected area designation and establishment is likely if only one province is involved. Hence, a protected area in the Net River catchment, in Quang Binh province, is recommended, since this area was clearly the best for pheasants and other wildlife. Forest protection in the Ke Go Lake catchment, preferably in an area contiguous with the Net River catchment, should also be pursued, although it should not take precedence over the latter area. Survival of forest in this area, as Watershed Protection Forest, will assist in the conservation of biodiversity as well as protect the shores of the lake from erosion and mitigate siltation of the lake itself.

\section{National and provincial capacity to manage protected areas}

Thai Van Trung (1985) noted that the management of reserves in Vietnam, undertaken by forestry personnel, is generally inadequate, with too few staff 
and irregular, inadequate, budget allocations. This situation persists, particularly in view of the increasing numbers of protected areas that have been established since 1985, with most of them lacking any formal management or protection (Nguyen $\mathrm{Cu}$ and Eames 1993). If a protected area is to be established in the Net River watershed, effective management will urgently be required to control and regulate human activities in the area, since it lies within an isolated forest block surrounded by very large numbers of rural people. Without the cooperation of these people, and an effort to inform them of the legal status of the forest and the implications for resource use within and around the area, it is unlikely that pheasants and other wildlife will benefit from the establishment of a protected area. As noted by Nguyen $\mathrm{Cu}$ and Eames (1993), the continued pressure on protected areas can be attributed to political and social problems, as well as to economic development.

A pilot project that aims to address some of the economic and social problems as a means to protect forest in the Ky Thuong district of Ha Tinh province was set up in 1993/1994. The success of this project should be carefully monitored, since it aims to protect wildlife in a 700 ha area of forest that is contiguous with the Net River/Ke Go Lake water catchment. If successful, similar types of community actions could be recommended as a means of stimulating regulation of hunting and logging activities in the Net River catchment. This project, funded by Oro Verde and implemented with the assistance of the Centre for Natural Resources Management and Environmental Studies and the provincial office of the Ministry of Science, Technology and the Environment, offers alternative sources of income to poor rural people who have traditionally exploited natural resources in surrounding forests. A small number of staff are employed by the project to monitor and discourage illegal activities within the reserve. Logging and hunting are strictly prohibited, although the collection of rattans is permitted. Villagers in the district have been provided with loans to purchase high-yield rice varieties, bee-keeping and honey-making equipment and orange tree saplings as part of a fruit-tree improvement project. Four small hydroelectric generators have also been installed in local villages as part of the project.

FIPI has the responsibility, within the Ministry of Forestry, for surveying protected areas and preparing management plans for them. The Ministry of Forestry is responsible for coordinating State Committees, Ministries and People's Committees in establishing, planning and protecting forbidden forests, as well as defining boundaries both on maps and on the ground. People's Committees that have forbidden forests within their area are responsible for providing information on the regulations to local residents, as well as organizing law enforcement patrols. Hence the establishment and management of a protected area is a complex issue that requires efficient coordination. The appointment of an individual within the Ministry of Forestry to work full time on this issue would greatly speed up the process.

\section{Development of a management plan for the Net River watershed}

According to the Forest Protection Department in Dong Hoi, the Quang Binh provincial capital, active protection of Special-Use Forests, whether for watershed protection or other reasons, cannot be implemented until such time as a 
management plan has been finished (by FIPI) and endorsed. This can take several years, and during this time natural resources within the reserve, such as timber, continue to be exploited. Hence some urgency should be placed on providing the necessary resources for FIPI and collaborating agencies to draw up a management plan for the area that is proposed in this report as a SpecialUse Forest. In Vietnam, feasibility studies are required before a management plan can be developed.

A moratorium on logging and hunting in the Net River watershed and any adjacent areas proposed for designation as Special-Use Forest would assist in ameliorating the effects of activities that would otherwise undermine the conservation value of the area during the management planning process. Such a moratorium would need to be endorsed and implemented by the provincial Ministry of Forestry offices.

\section{Threats to pheasant populations}

Hunting and habitat degradation and loss are the two major threats faced by all species of pheasant in the Annamese Lowlands. These two threats, when combined, pose a serious threat to the long-term survival of endemic pheasants in the Annamese Lowlands EBA. Vietnamese Pheasant is further threatened by international demand for live specimens. These threats are discussed below.

Although pheasants in South-East Asia are essentially forest birds, many species show a considerable tolerance to habitat modification. Studies in Malaysia, for example, have documented the persistence of populations of Great Argus Argusianus argus and Crested Fireback Lophura ignita (Johns 1986, Lambert 1990, 1992) in selectively logged forests. Crestless Fireback L. erythrophthalma also occurs in logged areas in Peninsular Malaysia (F.R.L. pers. obs.) whilst the presence of Siamese Fireback in seriously degraded habitat including scrub is documented (Eames et al. 1989).

With respect to endemic pheasants in the Annamese Lowlands of Vietnam, little is known about their habitat requirements or tolerance of logging and other resource-gathering activities. Whilst nothing can be said about the effect of these factors on Edwards's Pheasant or Imperial Pheasant, data collected during the 1994 survey strongly indicate the presence of Vietnamese Pheasant within areas of forest that have been seriously degraded around Ke Go Lake. In this area, however, high levels of hunting may obscure the tolerance level of this species to habitat modification, and it is impossible to conclude with certainty, from the limited evidence available, whether or not Vietnamese Pheasants thrive in logged habitats.

Certainly, the fact that Vietnamese Pheasant was observed daily in an area with good closed-canopy forest (Net River watershed), but was found to be exceedingly rare in the degraded forest around Ke Go Lake, suggests that this species may need closed-canopy forest. As far as could be judged, both these areas are subject to high levels of trapping, although hunting pressure in the $\mathrm{Ke}$ Go Lake catchment is likely to have been more intense and chronic than in the closed-canopy forests in the Net River catchment. Hence differences in habitat are more likely to be the cause for apparent differences in abundance. It is therefore recommended that every effort is made to ensure that extensive 
areas of closed-canopy and lightly logged forest are included within any protected area set up to protect this species.

The inclusion of such forest may also be important for the survival of other restricted-range species, such as Short-tailed Scimitar-babbler and Grey-faced Tit-babbler, neither of which was observed in seriously degraded forest. Whilst their exact habitat requirements are little known, the latter appears to favour the canopy of tall forest trees in the Annamese Lowlands, and certain species of terrestrial babbler are among the group of species that is most vulnerable to the effects of selective logging and forest disturbance in other parts of SouthEast Asia (Lambert 1990, 1992). Hence efforts to preserve appropriate closedcanopy forests will not only protect Vietnamese Pheasants, but will also benefit sympatric restricted-range bird species.

The Vietnam Forestry Sector Review (Ministry of Forestry 1991) notes that "Levels of hunting in Vietnam are horrible ... Most forests, even in nature reserves, are almost hunted out ... The ground birds have been trapped and snared to very low densities". Widespread hunting within the forests of the Annamese Lowlands, as documented in this and during previous bird surveys, has no doubt had an effect on pheasant populations. Nevertheless, although pheasants should be relatively easy to capture, it is of interest that only one individual was caught in the snare lines that were set in the Net River catchment, in an area where Vietnamese Pheasants were observed to be common. This would suggest that pheasants may be familiar with and avoid such traps. The fact that Vietnamese Pheasants persist in areas where trapping has been intensive, probably for many years, suggests some degree of resilience, although it may be that their persistence is partly dependent on influx of individuals from areas where trapping levels are lower. In the Ke Go Lake catchment, trapping levels have probably been higher and have a longer history than in the Net River watershed: this could be one explanation of why Vietnamese Pheasants apparently occur at much lower densities in the former area than in the latter.

Siamese Fireback and Imperial Pheasant, but not Vietnamese Pheasant, are afforded protection on paper since they are both listed in the Ministerial Decision on the List of Endangered Forest Flora and Fauna: Protection and Management Regulations (1992). The inclusion of Vietnamese and Edwards's Pheasant on this list would enhance the legal basis for their protection, and it is recommended that these species be proposed for inclusion on this list at the earliest opportunity. Whilst such laws provide the basis for protection of Imperial Pheasant and other listed wildlife, there is little, if any, motivation or effort to implement this Ministerial Decision, and it is also likely that rural people using forests where endangered species occur are unaware of it.

\section{Distribution and sympatry of pheasants in Vietnam}

One question that was constantly posed during the course of the surveys was whether or not more than two species of Lophura pheasant could occur sympatrically in the lowlands of Vietnam, and whether other terrestrial species might be used as indicators of the terrestrial avifaunal composition. Some of these 
other terrestrial bird species are much more vocal than Lophura pheasants, and their presence more easily detected despite often incredibly shy behaviour.

Whilst there are twelve species of Lophura pheasant (Sibley and Monroe 1990), in most parts of Asia no more than two species are known to occur sympatrically. For example, L. inornata and L. erythrophthalma occur sympatrically in the lowlands throughout much of their range, apparently separated by microhabitat preferences (Davison 1979). In some parts of Borneo Bulwer's Pheasant L. bulweri may occur sympatrically with these latter two species, although this has not been conclusively documented. L. bulweri is, anyway, primarily a bird of the hills whereas L. erythrophthalma is principally found in the lowlands, so sympatry is unlikely between more than two species in Borneo. Where $L$. nycthemera and $L$. diardi occur together, they are normally separated by altitude and/or habitat, with $L$. diardi usually at lower altitudes and in flatter forest than L. nycthemera.

Vietnam has more species of Lophura pheasant than any other country, with five species, all of which are known from the Annamese Lowlands. The presence of at least three, L. imperialis, L. hatinhensis and L. diardi, in the Cat Bin/ Net River area has been known since 1990 when Robson et al. (1991, 1993) conducted surveys in that area, but the exact locality of the collection site for L. imperialis remains unknown. Hunters claimed that the specimen came from $12 \mathrm{~km}$ to the west, which lies on the edge or within the Net River catchment. They also claimed to have trapped L. hatinhensis in the same snare line.

Evidence that these two species occur together in Vietnam is therefore strong, and, further south, Delacour and Jabouille (1931) reported that L. imperialis seemed to be found in the same areas as $L$. edwardsi, although they had previously stated (1925) that $L$. imperialis replaced $L$. edwardsi in the more northern part of Annam. Whilst this survey has shown that L. nycthemera and probably $L$. diardi (based on hunters reports) also occur in the same forest block as $L$. imperialis and $L$. hatinhensis, there is still no evidence that more than two species occur together at the local level (Table 3). Clearly, if only two species can survive together, then species with a competitive advantage could displace other Lophura pheasants following habitat modification, and it could be speculated that $L$. diardi, which is known to do well in scrub and secondary forest, might displace species such as L. imperialis in areas where forests had been severely modified. Until more is known about the ecology and habitat requirements of these species, it would be pragmatic to assume that closed-canopy forest was important for their survival.

\section{International trade of threatened pheasants for aviculture}

Vietnam became a signatory to CITES, the Convention on International Trade in Endangered Species of Wild Fauna and Flora, in 1994. Under the provisions of the convention, species listed on Appendix I cannot be traded internationally unless they are certified to be second-generation captive-bred stock by the exporting country. At present, Lophura edwardsi and L. imperialis are listed on CITES Appendix I, but $L$. hatinhensis is not protected by CITES. The inclusion of this species on CITES Appendix I should be a priority, especially since many 
Table 3. Sympatry amongst larger terrestrial birds at sites visited in the Annamese Lowlands EBA

\begin{tabular}{|c|c|c|c|c|c|c|}
\hline Species & $\mathrm{KQ}$ & $\mathrm{KB}$ & CB & NR & PN & RB \\
\hline $\begin{array}{l}\text { Arborophila brunneopectus Bar-backed } \\
\text { Partridge }\end{array}$ & * & * & * & * & * & $*$ \\
\hline $\begin{array}{l}\text { Arborophila charltonii Chestnut-necklaced } \\
\text { Partridge }\end{array}$ & * & * & & * & $?$ & $*$ \\
\hline $\begin{array}{l}\text { Gallus gallus Red Junglefowl } \\
\text { Lophura hatinhensis Vietnamese Pheasants }\end{array}$ & * & * & * & * & * & $*$ \\
\hline Lophura imperialis Imperial Pheasant & & $?$ & $?$ & * & & $?$ \\
\hline $\begin{array}{l}\text { Lophura nycthemera Silver Pheasant } \\
\text { Lophura diardi Siamese Fireback }\end{array}$ & * & * & $*$ & $?$ & * & $*$ \\
\hline $\begin{array}{l}\text { Polyplectron bicalcaratum Grey } \\
\text { Peacock-pheasant }\end{array}$ & * & * & * & * & * & * \\
\hline $\begin{array}{l}\text { Rheinardia ocellata Crested Argus } \\
\text { Carpococcyx renauldi Coral-billed } \\
\text { Ground-cuckoo }\end{array}$ & * & * & * & * & * & * \\
\hline $\begin{array}{l}\text { Total number of Lophura recorded at site: } \\
\text { Minimum number of large ground birds }\end{array}$ & $\begin{array}{l}1 \\
7\end{array}$ & $\begin{array}{l}2+ \\
8+\end{array}$ & $\begin{array}{l}2+ \\
4+\end{array}$ & $\begin{array}{l}2+ \\
8+\end{array}$ & $\begin{array}{l}1 \\
5\end{array}$ & $\begin{array}{c}2 \\
7^{+}\end{array}$ \\
\hline
\end{tabular}

Sites: KQ, Kim Quang; KB, Khe Buoi; CB, Cat Bin (data from Robson et al, 1993 and local informants); NR, Net River; PN, Phuong Nha; RB, Rao Bong watershed. *, present; $\left({ }^{*}\right)$, present but rare; ?, presence uncertain.

${ }^{1}$ Blue-rumped Pitta Pitta soror, Bar-bellied Pitta Pitta elliotii and Emerald Dove Chalcophaps indica also occur at all sites.

pheasant breeders are now actively seeking this species to house in their private collections, thus encouraging the collection of wild-caught specimens.

Hanoi Zoo has already been offered a substantial financial reward for providing live specimens of $L$. hatinhensis. However, the export of this species to Europe will contribute nothing towards its conservation, and is only likely to increase its value, leading to increased incentives to catch specimens. We would therefore strongly urge aviculturists to contribute their funds to active in situ conservation projects based in Vietnam, rather than to captive breeding (whether in Vietnam or outside the country).

\section{International importance of Phong Nha}

Two important discoveries were made in Phong Nha Cultural and Historical Site that raise the international importance of this protected area: the discovery of Sooty Babbler and Hatinh leaf-monkey within the forests on limestone. Whilst Sooty Babbler is also known from Laos, recent searches there have failed to find it (T. Evans pers. comm.) and it has not been seen there since its discovery in 1920 (Collar et al. 1994). Hatinh leaf-monkey is unknown from any other site. Hence, on present knowledge, Phong Nha is the only place in the world at which these two taxa are extant. Hatinh leaf-monkey is considered Endangered by IUCN (WCMC 1993).

Whilst the area of forest on limestone in Phong Nha and its surrounding area is substantial, the distribution and population size of these two species within these areas has yet to be determined. It is recommended, therefore, that further surveys are conducted in this area, in particular to assess the exact habitat requirements of both taxa and to estimate their total population sizes. Both taxa 
were observed in primary forest on limestone, a habitat that was not common in the area visited. The extent of suitable habitat may therefore be much smaller than the large size of the limestone massif suggests, and every effort should be made to curtail the illegal logging activities that were observed in the virtually pristine forests of the reserve. Although there is a functional park headquarters and a guard station on the road into the park, no active preventative measures were being taken by park staff to stop illegal activities such as logging.

\section{Recommendations}

Our principal recommendations are as follows.

1. The apparent high biodiversity value of the forests of the Net River watershed renders their current designation as Production Forest inappropriate, and this area should be redesignated as Special-Use Forest.

2. A moratorium on proposed logging activities in the Net River watershed should immediately be implemented by the Ministry of Forestry.

3. A full feasibility study for the establishment of a protected area should be undertaken in 1995 in the Net River watershed, as part of the ongoing BirdLife International project, aiming to determine the importance of the watershed for Vietnamese and Imperial Pheasants, complete a faunal and floral inventory, determine the extent and pattern of human occupancy and utilization of the area, and propose the boundary for the nature reserve.

4. In view of the apparent habitat preferences of Vietnamese Pheasant, any protected area should include the maximum extent of closed-canopy or lightly logged areas of forest.

5. The forests to the south and west of Ke Go Lake should be excluded from any strict nature reserve but retain the designation of Watershed Protection Forest.

6. The hydrological value of the forests of Ke Go Lake require active measures to be taken by $\mathrm{Ha}$ Tinh Forest Protection Department to curtail logging activities in Ke Thuong and Cam Xuyen districts.

7. On the completion of recommendation 3, BirdLife International, in conjunction with the Ministry of Forestry, should seek bilateral funding for the establishment of a protected area in the Net River watershed.

8. Given our acute lack of knowledge of Imperial Pheasant, further surveys should be undertaken to locate the species and possible sites for protectedarea development within its range, focusing on forested areas in Quang Binh province, including the Net River watershed.

9. Given the international significance of Phong Nha Cultural and Historical Site owing to the presence of Sooty Babbler and Hatinh leaf-monkey, this site should be redesignated as a Nature Reserve, with financial resources for such a development a priority.

10. Further surveys at Phong Nha should be undertaken to assess habitat requirements and total estimated population size of Sooty Babbler and Hatinh leaf-monkey. 
11. Measures should be taken to protect forest in the valley bottoms between areas of karst in Phong Nha Cultural and Historical Site.

12. Measures should be taken to conserve the forest in the valley bottoms south of Kim Quang Substation in Vu Quang Nature Reserve. This area supports populations of threatened mammals including red-shanked douc langur Pygathrix nemaeus, crested gibbon Hylobates gabriellae and Owston's banded civet Hemigalus owstoni.

13. Edwards's and Vietnamese Pheasants should be included on the Vietnamese list of Endangered Forest Fauna and Flora.

14. Vietnamese Pheasant should be included on Appendix I of CITES at the earliest opportunity.

\section{Acknowledgements}

Fieldwork was conducted as a collaborative project between BirdLife International and the Species Survival Commission of IUCN, the World Conservation Union. The project comprised part of the BirdLife International "Conservation of Biodiversity in the Annamese Lowlands and the Da Lat Plateau, Vietnam" project, funded by the Commission of European Communities (DGl) through Contract B7-5041/93/11, and part of the NWF/IUCN/WWF Programme on Endangered Species in Asia, funded primarily by NWF, the National Wildlife Federation.

We would like to extend our thanks to the following individuals and institutions for providing help and assistance to us in our work. In Hanoi at the Ministry of Forestry we owe particular thanks to Mr Nguyen Mau Tai, Director of the Forest Protection Department, Mr Bui Xuan Yen, Director of the International Cooperation Department, Mr Tran Dinh Dan, Vice-Director of the Forest Protection Department, Dr Nguyen Nhu Phuong, Chief, Management of National Forest Parks, Nature Reserves and Wildlife, Mr Pham Mong Giao, Senior Expert of Biology, Dr Nguyen Huu Dong, Director of Forest Resources and Environment Centre of FIPI, and Dr Nguyen Manh Cuong, Head of the Remote Sensing Section of the Forest Resources and Environment Centre, FIPI. We also thank Professor Dr Dang Huy Huynh, Director of the Institute of Ecology and Biological Resources, Hanoi, for permitting the secondment of N.C. to the project. We must also thank David Hulse and the staff of World Wildlife Fund Vietnam Programme, and Dr Jacques Lecup of the IUCN Vietnam office, for their assistance and use of office facilities.

In Ha Tinh province we would like to thank the guard station staff of Ho Ke Go Forest, Mr Duong Nguyen Thuy, Department of Science, Technology and Environment of Ha Tinh, Mr Duong Huu Long and Mr Du in Cam My, Cam Xuyen district. Thanks go to the staff at Vu Quang Border Station as well as at their Headquarters in Ha Tinh, and to Mr Le Kim in Kim Quang, Vu Quang, Huong Khe district. In Ky Anh district we would like to thank the staff of Ky Anh Forestry Enterprise, Mr Bui Tien Thanh, Chairman of Ky Thuong subdistrict, Mr Le Luy, Le Sau and Le Nam.

In Quang Binh province we thank Mr Bui Ngoc Tu, Vice-Chairman of the Provincial Forest Protection Department, Mr Nguyen Van Huyen, Vice- 
Chairman of Phong Nha Nature Reserve and his staff, Mr Hoang Que and the people of Truong Son village, Son Trach, Bo Trach district.

Tim Inskipp and Craig Robson kindly provided comments on an earlier version of this paper.

\section{Appendix 1. List of birds recorded at the five study sites, spring 1994}

The taxonomy and sequence of species follows Sibley and Monroe (1990).

* observed or heard by survey team member; $U=$ sighting uncertain; $\mathrm{L}=$ reported by local people; $S$ specimen or remains observed.

Status: $R$ = Restricted-range species (as defined by ICBP 1992), G = Globally threatened as defined by Collar et al. (1994) (excludes Near-threatened species).

\section{Study Sites:}

1. Kim Quang, Vu Quang Nature Reserve, Ha Tinh province

2. Khe Buoi, Ke Go Lake, Ha Tinh province

3. Net River watershed, Quang Binh province

4. Phong Nha Cultural and Historical Site, Quang Binh province

5. Truong Son village and Bong River watershed, Quang Binh province

\begin{tabular}{|c|c|c|c|c|c|c|c|}
\hline \multirow[t]{2}{*}{ Species } & \multirow[t]{2}{*}{ English name } & & \multicolumn{5}{|c|}{ Study site } \\
\hline & & & 1 & 2 & 3 & 4 & 5 \\
\hline Francolinus pintadeanus & Chinese Francolin & & * & * & & & \\
\hline Arborophila brunneopectus & Bar-backed Partridge & & $*$ & $*$ & $*$ & $*$ & * \\
\hline Arborophila charltonii & $\begin{array}{l}\text { Chestnut-necklaced } \\
\text { Partridge }\end{array}$ & G & $*$ & * & * & & * \\
\hline Gallus gallus & Red Junglefowl & & * & * & $*$ & $*$ & * \\
\hline Lophura nycthemera & Silver Pheasant & & * & * & & & * \\
\hline Lophura hatinhensis & Vietnamese Pheasant & GR & & $\mathrm{S}$ & $*$ & & \\
\hline Lophura diardi & Siamese Fireback & G & & & $\mathrm{L}$ & $*$ & $*$ \\
\hline Polyplectron bicalcaratum & Grey Peacock-pheasant & & * & * & * & $*$ & \\
\hline Rheinardia ocellata & Crested Argus & GR & $*$ & * & $*$ & & S \\
\hline Turnix & Buttonquail sp. & & $*$ & & & $*$ & \\
\hline Sasia ochracea & White-browned Piculet & & & & $*$ & $*$ & \\
\hline Picoides canicapillus & $\begin{array}{l}\text { Grey-capped } \\
\text { Woodpecker }\end{array}$ & & $*$ & $*$ & & & * \\
\hline Celeus brachyurus & Rufous Woodpecker & & * & * & $*$ & & \\
\hline Picus chloropus & Lesser Yellownape & & & * & & & \\
\hline Picus flavinucha & Greater Yellownape & & * & * & $*$ & $*$ & \\
\hline Picus vittatus & Laced Woodpecker & & & & & $*$ & \\
\hline Picus rabieri & $\begin{array}{l}\text { Red-collared } \\
\text { Woodpecker }\end{array}$ & G & * & * & $*$ & * & * \\
\hline Chrysocolaptes lucidus & Greater Flameback & & & & * & & \\
\hline Blythipicus pyrrhotis & Bay Woodpecker & & * & * & & $*$ & \\
\hline Mulleripicus pulverulentis & Great Slaty Woodpecker & & & * & & & \\
\hline Megalaima langrandieri & Red-vented Barbet & & $*$ & * & $*$ & $*$ & $*$ \\
\hline Megalaima faiostricta & Green-eared Barbet & & * & & $*$ & & \\
\hline Megalaima australis & Blue-eared Barbet & & & & & $*$ & \\
\hline Anthracoceros albirostris & Oriental Pied Hornbill & & & & & $*$ & \\
\hline Buceros bicornis & Great Hornbill & & $*$ & * & & $\mathrm{S}$ & \\
\hline Ptiloaemus tickelli & Brown Hornbill & & $*$ & * & $*$ & $*$ & * \\
\hline Aceros undulatus & Wreathed Hornbill & & & & $*$ & $\mathrm{~S}$ & \\
\hline Harpactes erythrocephalus & Red-headed Trogon & & * & * & $*$ & $*$ & \\
\hline
\end{tabular}


Appendix 1 - contd.

\begin{tabular}{|c|c|c|c|c|c|c|c|}
\hline \multirow[t]{2}{*}{ Species } & \multirow[t]{2}{*}{ English name } & & \multicolumn{5}{|c|}{ Study site } \\
\hline & & & 1 & 2 & 3 & 4 & 5 \\
\hline Alcedo hercules & Blyth's Kingfisher & G & $*$ & * & $*$ & & \\
\hline Alcedo atthis & Common Kingfisher & & & $*$ & & & \\
\hline Ceyx erithacus & Black-backed Kingfisher & & $*$ & * & & $*$ & \\
\hline Halcyon coromanda & Ruddy Kingfisher & & $*$ & & & & \\
\hline Halcyon smyrnensis & $\begin{array}{l}\text { White-throated } \\
\text { Kingfisher }\end{array}$ & & $*$ & * & & * & \\
\hline Megaceryle lugubris & Crested Kingfisher & & $*$ & & & & * \\
\hline Ceryle rudis & Pied Kingfisher & & & * & & & \\
\hline Nyctyornis athertoni & Blue-bearded Bee-eater & & & $*$ & $*$ & * & \\
\hline Merops viridis & Blue-throated Bee-eater & & $*$ & $*$ & & $*$ & \\
\hline Cuculus & Hawk-cuckoo sp. & & $*$ & & & & \\
\hline Cuculus micropterus & Indian Cuckoo & & $*$ & & * & & \\
\hline Cacomantis sonneratii & Banded Bay Cuckoo & & & & * & & \\
\hline Cacomantis merulinus & Plaintive Cuckoo & & $*$ & & & * & \\
\hline Chrysococcyx maculatus & Asian Emerald Cuckoo & & $*$ & & & & \\
\hline Surniculus lugubris & Drongo Cuckoo & & * & $*$ & * & * & \\
\hline Eudynamys scolopacea & Asian Koel & & $*$ & & & & \\
\hline Phoenicophaeus tristis & Green-billed Malkoha & & $*$ & $*$ & * & $*$ & \\
\hline Carpococcyx renauldi & $\begin{array}{l}\text { Coral-billed Ground- } \\
\text { cuckoo }\end{array}$ & & $*$ & * & $*$ & & \\
\hline Centropus sinensis & Greater Coucal & & $*$ & & * & * & \\
\hline Psittacula alexandri & Red-breasted Parakeet & & & & $*$ & & \\
\hline Collacalia brevirostris & Himalayan Swiftlet & & $*$ & & & & \\
\hline Hirundapus cochinchinensis & Silver-backed Needletail & & $*$ & & & & \\
\hline Cypsiurus balasiensis & Asian Palm Swift & & $*$ & & & * & \\
\hline Tyto alba & Barn Owl & & & & & * & \\
\hline Otus spilocephalus & Mountain Scops-owl & & $*$ & * & * & * & \\
\hline Otus bakkamoena & Collared Scops-owl & & * & & & * & \\
\hline Strix leptogrammica & Brown Wood-owl & & & & $*$ & & \\
\hline Glaucidium brodiei & Collared Owlet & & & * & * & $*$ & \\
\hline Glaucidium cuculoides & Asian Barred Owlet & & * & * & * & * & \\
\hline Caprimulgus macrurus & Large-tailed Nightjar & & $*$ & & & & \\
\hline Caprimulgus & Nightjar sp. & & & & & * & \\
\hline Streptopelia chinensis & Spotted Dove & & * & * & & * & \\
\hline Streptopelia orientalis & Oriental Turtle Dove & & & & & $*$ & \\
\hline Streptopelia tranquebarica & Red Collared Dove & & & & & $*$ & \\
\hline Macropygia unchall & Barred Cuckoo-dove & & $*$ & & & & \\
\hline Chalcophaps indica & Emerald Dove & & * & * & * & * & * \\
\hline Treron curvirostra & Thick-billed & & * & * & * & * & * \\
\hline & Green-pigeon & & & & & & \\
\hline Treron apicauda & Pin-tailed Green-pigeon & & & $*$ & * & & \\
\hline Ducula badia & $\begin{array}{l}\text { Mountain Imperial- } \\
\text { pigeon }\end{array}$ & & $*$ & * & * & & \\
\hline Amaurornis phoenicurus & White-breasted & & & & & * & \\
\hline & Waterhen & & & & & & \\
\hline Vanellus indicus & Red-wattled Lapwing & & & $*$ & & & \\
\hline Aviceda leuphotes & Black Baza & & & & * & & \\
\hline Pernis ptilorhynchus & Oriental Honey-buzzard & & * & & * & & \\
\hline Ichthyophaga humilis & Lesser Fish-eagle & & * & & & & \\
\hline Spilornis cheela & Crested Serpent-eagle & & * & & * & * & \\
\hline Accipiter trivirgatus & Crested Goshawk & & * & * & * & * & \\
\hline Ictinaetus malayensis & Black Eagle & & * & $*$ & & * & \\
\hline Spizaetus nipalensis & Mountain Hawk-eagle & & * & & & & \\
\hline Microhierax melanoleucus & Pied Falconet & & * & & & & \\
\hline
\end{tabular}




\begin{tabular}{|c|c|c|c|c|c|c|c|}
\hline \multirow[t]{2}{*}{ Species } & \multirow[t]{2}{*}{ English name } & & \multicolumn{5}{|c|}{ Study site } \\
\hline & & & 1 & 2 & 3 & 4 & 5 \\
\hline Falco peregrinus & Peregrine Falcon & & & & & * & \\
\hline Dupetor flavicollis & Black Bittern & & $*$ & & & & \\
\hline Pelecanus philippensis & Spot-billed Pelican & $G$ & $\mathbf{S}$ & & & & \\
\hline Pitta soror & Blue-rumped Pitta & & $*$ & $*$ & $*$ & $*$ & \\
\hline Pitta elliotti & Bar-bellied Pitta & & $*$ & $*$ & $*$ & $*$ & * \\
\hline Pitta moluccensis & Blue-winged Pitta & & & & & $*$ & \\
\hline Serilophus lunatus & Silver-breasted Broadbill & & & $*$ & $*$ & & \\
\hline Psarisomus dalhousiae & Long-tailed Broadbill & & & $*$ & & $*$ & \\
\hline Irena puella & Asian Fairy Bluebird & & $*$ & $*$ & $*$ & $*$ & * \\
\hline Chloropsis cochinchinensis & Blue-winged Leafbird & & $*$ & & $*$ & * & \\
\hline Chloropsis aurifrons & Golden-fronted Leafbird & & & $*$ & $*$ & & \\
\hline Chloropsis hardwickii & Orange-bellied Leafbird & & $*$ & * & * & & \\
\hline Lanius schach & Long-tailed Shrike & & $*$ & $*$ & & $*$ & * \\
\hline Urocissa whiteheadi & White-winged Magpie & & $*$ & $*$ & $*$ & * & * \\
\hline Cissa chinensis & Green Magpie & & $*$ & & & $*$ & \\
\hline Cissa hypoleuca & Yellow-breasted Magpie & & $*$ & $*$ & $*$ & * & \\
\hline Dendrocitta vagabunda & Rufous Treepie & & & $*$ & & & \\
\hline Cripsirina temia & Racket-tailed Treepie & & $*$ & $*$ & & $*$ & $*$ \\
\hline Temnurus temnurus & Ratchet-tailed Treepie & & * & $*$ & $*$ & $*$ & $*$ \\
\hline Corous macrorhynchos & Large-billed Crow & & $*$ & $*$ & $*$ & $*$ & $*$ \\
\hline Artamus fuscus & Ashy Wood-swallow & & $*$ & * & & * & * \\
\hline Oriolus traillii & Maroon Oriole & & & $\mathrm{U}$ & $\mathrm{U}$ & & \\
\hline Coracina macei & Large Cuckoo-shrike & & $*$ & $*$ & * & $\mathrm{U}$ & * \\
\hline Coracina melaschistos & $\begin{array}{l}\text { Black-winged } \\
\text { Cuckoo-shrike }\end{array}$ & & & $*$ & & $*$ & \\
\hline Pericrocotus flammeus & Scarlet Minivet & & * & $*$ & $*$ & * & * \\
\hline Hemipus picatus & $\begin{array}{l}\text { Bar-winged } \\
\text { Flycatcher-shrike }\end{array}$ & & * & * & * & * & \\
\hline Rhipidura albicollis & White-throated Fantail & & $*$ & $*$ & * & * & $*$ \\
\hline Dicrurus macrocercus & Black Drongo & & & & & * & \\
\hline Dicrurus leucophaeus & Ashy Drongo & & $*$ & $*$ & $*$ & $*$ & $*$ \\
\hline Dicrurus annectans & Crow-billed Drongo & & & $\mathrm{U}$ & & $*$ & \\
\hline Dicrurus aeneus & Bronzed Drongo & & $*$ & $*$ & $*$ & $*$ & * \\
\hline Dicrurus hottentottus & Hair-crested Drongo & & $*$ & & $*$ & & \\
\hline Dicrurus paradiseus & $\begin{array}{l}\text { Greater Racket-tailed } \\
\text { Drongo }\end{array}$ & & $*$ & $*$ & * & $*$ & * \\
\hline Hypothymis azurea & Black-naped Monarch & & $*$ & $*$ & $*$ & $*$ & \\
\hline Terpsiphone paradisi & $\begin{array}{l}\text { Asian } \\
\text { Paradise-flycatcher }\end{array}$ & & * & & & & \\
\hline Aegithina tiphia & Common Iora & & $U$ & $U$ & $*$ & $*$ & $*$ \\
\hline Aegithina lafresnayei & Great Iora & & $*$ & $*$ & * & & \\
\hline Tephrodornis gularis & Large Wood-shrike & & $*$ & $*$ & $*$ & $*$ & \\
\hline Cinclus pallasii & Brown Dipper & & * & & & & \\
\hline Myiophonus caeruleus & Blue Whistling-thrush & & * & $*$ & & $*$ & \\
\hline Muscicapa dauurica & Asian Brown Flycatcher & & & $*$ & $*$ & & * \\
\hline Eumyius thalassina & Verditer Flycatcher & & & $*$ & & & \\
\hline Cyornis concreta & $\begin{array}{l}\text { White-tailed } \\
\text { Blue-flycatcher }\end{array}$ & & * & & * & & \\
\hline Cyornis hainanus & Hainan Blue-flycatcher & & $*$ & $*$ & $*$ & & \\
\hline Copsychus saularis & Oriental Magpie Robin & & $*$ & $*$ & $*$ & * & * \\
\hline Copsychus malabaricus & White-rumped Shama & & * & $*$ & $*$ & * & * \\
\hline Enicurus leschenaulti & White-crowned Forktail & & & * & $*$ & & * \\
\hline Enicurus schistaceus & Slaty-backed Forktail & & * & $*$ & * & $*$ & * \\
\hline Sturnus malabaricus & Chestnut-tailed Starling & & & * & & * & * \\
\hline
\end{tabular}


Appendix 1 - contd.

\begin{tabular}{|c|c|c|c|c|c|c|c|}
\hline \multirow[t]{2}{*}{ Species } & \multirow[t]{2}{*}{ English name } & & \multicolumn{5}{|c|}{ Study site } \\
\hline & & & 1 & 2 & 3 & 4 & 5 \\
\hline Sturnus sinensis & $\begin{array}{l}\text { White-shouldered } \\
\text { Starling }\end{array}$ & & & & & * & \\
\hline Sturnus nigricollis & Black-collared Starling & & $*$ & * & * & * & * \\
\hline Acridotheres tristis & Common Myna & & & * & & * & \\
\hline Acridotheres cristatelus & Crested Myna & & & * & & * & \\
\hline Gracula religiosa & Hill Myna & & * & * & * & * & * \\
\hline Ampeliceps coronatus & Golden-crested Myna & & & * & & & \\
\hline Sitta frontalis & Velvet-fronted Nuthatch & & & & * & & \\
\hline Parus major & Great Tit & & $*$ & & & $*$ & * \\
\hline Melanochlora sultanea & Sultan Tit & & * & * & * & * & * \\
\hline Hirundo rustica & Barn Swallow & & & * & & * & \\
\hline Pycnonotus melanicterus & Black-crested Bulbul & & $*$ & & * & * & \\
\hline Pycnonotus jocosus & Red-whiskered Bulbul & & $*$ & * & * & * & * \\
\hline Pycnonotus aurigaster & Sooty-headed Bulbul & & * & * & & * & \\
\hline Pycnonotus finlaysoni & Stripe-throated Bulbul & & $*$ & * & * & * & \\
\hline Alophoixus pallidus & Puff-throated Bulbul & & * & * & * & * & * \\
\hline Iole propinqua & Grey-eyed Bulbul & & * & $*$ & * & $*$ & * \\
\hline Hypsipetes leucocephalus & Black Bulbul & & $*$ & * & * & * & * \\
\hline Cisticola juncidis & Zitting Cisticola & & & $\mathrm{U}$ & & & \\
\hline Prinia inornata & Plain Prinia & & & * & & & \\
\hline Prinia hodgsoni & Grey-breasted Prinia & & & * & & & * \\
\hline Zosterops palpebrosus & Oriental White-eye & & * & * & * & * & * \\
\hline Acrocephalus bistrigiceps & $\begin{array}{l}\text { Black-browed } \\
\text { Reed-warbler }\end{array}$ & & $*$ & & & & \\
\hline Orthotomus atrogularis & Dark-necked Tailorbird & & $*$ & * & $*$ & * & * \\
\hline Phylloscopus ricketti & $\begin{array}{l}\text { Sulphur-breasted } \\
\text { Warbler }\end{array}$ & & & & & * & \\
\hline Phylloscopus davisoni & White-tailed Warbler & & & * & * & & * \\
\hline Garrulax perspicillatus & Masked Laughingthrush & & $*$ & * & & $U$ & \\
\hline Garrulax leucolophus & $\begin{array}{l}\text { White-crested } \\
\text { Laughingthrush }\end{array}$ & & * & * & * & $*$ & * \\
\hline Garrulax monileger & $\begin{array}{l}\text { Lesser Necklaced } \\
\text { Laughingthrush }\end{array}$ & & $*$ & * & * & $*$ & \\
\hline Garrulax chinensis & $\begin{array}{l}\text { Black-throated } \\
\text { Laughingthrush }\end{array}$ & & $*$ & * & * & * & * \\
\hline Garrulax pectoralis & $\begin{array}{l}\text { Greater Necklaced } \\
\text { Laughingthrush }\end{array}$ & & * & * & & & \\
\hline Malococincla abbotti & Abbott's Babbler & & & & & * & \\
\hline Pellorneum tickelli & Buff-breasted Babbler & & $*$ & $*$ & * & $*$ & * \\
\hline Pellorneum albiventre & Spot-throated Babbler & & & & & * & \\
\hline Pellorneum ruficeps & Puff-throated Babbler & & & * & * & * & \\
\hline Malacopteron cinereum & Scaly-crowned Babbler & & $*$ & * & * & * & * \\
\hline Pomatorhinus hypoleucos & Large Scimitar-babbler & & $*$ & * & * & $*$ & * \\
\hline Pomatorhinus schisticeps & $\begin{array}{l}\text { White-browed } \\
\text { Scimitar-babbler }\end{array}$ & & & * & & & \\
\hline Jabouilleia danjoui & $\begin{array}{l}\text { Short-tailed Scimitar- } \\
\text { babbler }\end{array}$ & RG & $\mathrm{U}$ & * & * & & * \\
\hline Napothera brevicaudata & Streaked Wren-babbler & & * & & * & * & * \\
\hline Napothera epilepidota & $\begin{array}{l}\text { Eye-browed } \\
\text { Wren-babbler }\end{array}$ & & * & * & * & & \\
\hline Stachyris ruficeps & Rufous-capped Babbler & & & * & & & \\
\hline Stachyris herberti & Sooty Babbler & RG & & & & * & \\
\hline Stachyris nigriceps & Grey-throated Babbler & & * & * & * & * & \\
\hline
\end{tabular}




\begin{tabular}{|c|c|c|c|c|c|c|c|}
\hline \multirow[t]{2}{*}{ Species } & \multirow[t]{2}{*}{ English name } & & \multicolumn{5}{|c|}{ Study site } \\
\hline & & & 1 & 2 & 3 & 4 & 5 \\
\hline Stachyris striolata & Spot-necked Babbler & & & * & * & * & * \\
\hline Macronous gularis & Striped Tit-babbler & & * & * & * & $*$ & * \\
\hline Macronous kelleyi & Grey-faced Tit-babbler & $R$ & $*$ & $*$ & $*$ & & \\
\hline Gampsorhynchus rufulus & White-hooded Babbler & & * & & * & & \\
\hline Alcippe rufogularis & $\begin{array}{l}\text { Rufous-throated } \\
\text { Fulvetta }\end{array}$ & & & * & & & * \\
\hline Alcippe peracensis & Mountain Fulvetta & & * & * & * & * & * \\
\hline Yuhina castaniceps & Striated Yuhina & & & & & $*$ & \\
\hline Yuhina zantholeuca & White-bellied Yuhina & & * & * & * & * & * \\
\hline Paradoxornis davidianus & Short-tailed Parrotbill & G & & * & & & \\
\hline Dicaeum chrysorrheum & $\begin{array}{l}\text { Yellow-vented } \\
\text { Flowerpecker }\end{array}$ & & * & * & * & * & * \\
\hline Dicaeum concolor & Plain Flowerpecker & & & & * & & \\
\hline Dicaeum cruentatum & $\begin{array}{l}\text { Scarlet-backed } \\
\text { Flowerpecker }\end{array}$ & & & * & * & & * \\
\hline Anthreptes singalensis & Ruby-cheeked Sunbird & & & & * & & \\
\hline Hypogramma hypogrammicum & Purple-naped Sunbird & & & & * & * & \\
\hline Aethopyga christinae & Fork-tailed Sunbird & & * & * & * & * & * \\
\hline Aethopyga siparaja & Crimson Sunbird & & * & * & * & * & * \\
\hline Nectarinia jugularis & Olive-backed Sunbird & & * & * & & & \\
\hline Arachnothera magna & Streaked Spiderhunter & & * & * & * & * & * \\
\hline Passer montanus & Eurasian Tree Sparrow & & * & $*$ & $*$ & $*$ & * \\
\hline Motacilla cinerea & Grey Wagtail & & * & * & & * & * \\
\hline Motacilla alba & White Wagtail & & & * & & $*$ & \\
\hline Anthus richardi & Richard's Pipit & & & $\mathrm{U}$ & & $\mathrm{U}$ & \\
\hline Lonchura striata & White-rumped Munia & & & * & & * & * \\
\hline Lonchura punctulata & Scaly-breasted Munia & & & * & & & \\
\hline
\end{tabular}

\section{Appendix 2. Non-volant mammals observed at the various study sites}

$\mathrm{O}=$ Observed; $\mathrm{H}=$ Heard; $\mathrm{M}=$ Material evidence; $\mathrm{R}=$ Reliably reported. Status as defined in WCMC (1993): $\mathrm{E}=$ Endangered, $\mathrm{V}=$ Vulnerable, $\mathrm{I}=$ Indeterminate, $\mathrm{K}=$ Insufficiently known. Taxonomy and sequence follows Corbett and Hill (1992). See Appendix 1 for list of study sites.

\begin{tabular}{|c|c|c|c|c|c|c|}
\hline Species & Status & 1 & 2 & 3 & 4 & 5 \\
\hline \multicolumn{7}{|l|}{ Pangolin sp. Manis sp. (>javanica) } \\
\hline Northern tree shrew Tupaia belangeri & & $\mathrm{O}$ & $\mathrm{O}$ & $\mathrm{O}$ & $\mathrm{O}$ & $\mathrm{O}$ \\
\hline Assamese macaque Macaca assamensis & & & & & & $\mathrm{O}$ \\
\hline Rhesus macaque Macaca mulatta & & $\mathrm{O}$ & & & & \\
\hline Bear macaque Macaca arctoides & $\mathrm{K}$ & & & & $\mathrm{O}$ & \\
\hline $\begin{array}{l}\text { Hatinh leaf-monkey Semnopithecus (f.) } \\
\text { hatinhensis }\end{array}$ & $\mathrm{E}$ & & & & $\mathrm{O}$ & \\
\hline $\begin{array}{l}\text { Red-shanked douc langur Pygathrix } n \text {. } \\
\text { nemaeus }\end{array}$ & E & $\mathrm{O}$ & & & & \\
\hline Crested gibbon Hylobates gabriellae & $\mathrm{E}$ & $\mathrm{O}$ & & $\mathrm{H}$ & $\mathbf{R}$ & \\
\hline Bear sp. Ursus ?malaysanus & $\mathrm{V}$ & $\mathbf{R}$ & & $\mathbf{R}$ & $\mathrm{M}$ & \\
\hline Yellow-throated martin Martes flavigula & & $\mathrm{O}$ & $\mathrm{O}$ & & & \\
\hline Otter sp. Lutra sp. & $\mathrm{K}$ & $\mathrm{O}$ & & & & \\
\hline Civet sp. Viverra zibetha/megaspila & & $\mathrm{O}$ & & & & \\
\hline Masked palm civet Paguma larvata & & $\mathrm{O}$ & & & & \\
\hline
\end{tabular}


Appendix 2 - contd.

\begin{tabular}{lcccccc}
\hline Species & Status & $\mathbf{1}$ & 2 & 3 & 4 & 5 \\
\hline Owston's banded civet Hemigalus owstoni & $\mathrm{I}$ & $\mathrm{O}$ & & & & \\
Crab-eating mongoose Herpestes urva & & $\mathrm{O}$ & & $\mathrm{O}$ & & \\
Tiger Panthera tiger & $\mathrm{E}$ & $\mathrm{R}^{*}$ & & & & \\
Asian elephant Elephas maximus & $\mathrm{E}$ & $\mathrm{R}^{*}$ & & & & \\
Wild boar Sus scrofa & & $\mathrm{M}$ & $\mathrm{M}$ & $\mathrm{O}$ & $\mathrm{M}$ & $\mathrm{M}$ \\
Lesser mouse deer Tragulus javanicus & & $\mathrm{O}$ & & & & \\
Sambar deer Cervus unicolor & & $\mathrm{M}$ & $\mathrm{M}$ & $\mathrm{M}$ & & \\
Indian muntjac Muntiacus muntjac & $\mathrm{R}$ & & $\mathrm{H}$ & $\mathrm{H}$ & \\
Giant muntjac Megamuntiacus vuquangensis & $\mathrm{N}$ & $\mathrm{M}^{*}$ & & $\mathrm{H}$ ? & & \\
Vu Quang ox Pseudoryx nghetinhensis & $\mathrm{I}$ & $\mathrm{M}^{*}$ & & & & \\
Serow Capricornis sumatraensis & $\mathrm{M}^{*}$ & & & & \\
Black giant squirrel Ratufa bicolor & & $\mathrm{O}$ & & $\mathrm{O}$ & $\mathrm{O}$ & \\
Pallas's squirrel Callosciurus erythraeus & & $\mathrm{O}$ & & $\mathrm{O}$ & $\mathrm{O}$ & \\
Squirrel Tamiops sp. & & $\mathrm{O}$ & & $\mathrm{O}$ & $\mathrm{O}$ & \\
Red-cheeked squirrel Dremomys rufigenis & & & & & $\mathrm{O}$ & $\mathrm{O}$ \\
Long-tailed giant rat Leopoldamys sabanus & & $\mathrm{O}$ & & & & \\
Indochinese porcupine Hystrix brachyura & & $\mathrm{M}$ & & & & \\
\hline
\end{tabular}

* Evidence may not refer to the lowland forest study site, although the species may have occurred here formerly.

Appendix 3. Biometrics (mm), bare part colours and moult of juvenile male Vietnamese Pheasant trapped on 1 July 1994

\section{Measurements:}

Bill: length of exposed culmen $\quad 28$

nostril to tip $\quad 15$

gape to tip $\quad 31$

$\begin{array}{ll}\text { Tarsus } & 74\end{array}$

Middle toe to toe tip $\quad 49$

Hind claw length $\quad 6$

Wing length (maximum chord) $\quad 196$

Tail length $\quad 205$

Bare parts: Facial skin red extending across lores, the red patch being $34 \mathrm{~mm}$ long and $22 \mathrm{~mm}$ from top to bottom. Iris brown, legs pink-red.

Moult: Both wings had secondaries all new except outermost. Primaries all new except outermost four. Primaries $4-6$ (counted from centre of wing outwards) in pin. Head moult was just beginning: some blue feathers were present on the hindcrown. Outermost two pairs of tail feathers were growing, the rest were old. Some body feathers were new, with blue feathers on the scapulars and neck.

\section{References}

Allport, G., Ausden, M., Hayman, P. V., Robertson, P. and Wood, P. (1989) The conservation of the birds of the Gola Forest, Sierra Leone. Cambridge, U.K.: International Council for Bird Preservation (Study Report 38).

Anderson, E. S. (1992) Der Vietnamfasan - eine eigenstandige Art? Tropische Vögel 13: 97-99. 
Anon. (1993a) Summary management plan of Pu Mat Nature Reserve, Nghe An province. Unpublished report to Ministry of Forestry, Hanoi.

Anon. (1993b) Ho Ke Go proposed conservation and development project. Unpublished draft report to BirdLife International.

Baker, E. C. S. (1920) [Description of new genera, species and subspecies from a collection of birds collected by E. G. Herbert in Siam.] Bull. Brit. Orn. Club 41: 10-11.

Baker, E. C. S. (1921) [Diagnosis of the genus Nigravis.] Bull. Brit. Orn. Club 41: 101.

BAP Planning Team (1993) Biodiversity Action Plan for Vietnam (Draft).

Bloch, H., Poulsen, M. K., Rahbek, C. and Rasmussen, J. F. (1991) A survey of the montane forest avifauna of the Loja province, southern Ecuador. Cambridge, U.K.: International Council for Bird Preservation (Study Report 49).

Casella, F., McVean, G., Brunton, D., Robson, R. and King, R. (1994) Bach Ma '93: An Oxford University Entomological Expedition to Vietnam. Unpublished.

Collar, N. J., Crosby, M. J. and Stattersfield, A. J. (1994) Birds to watch 2: the world list of threatened birds. Cambridge, U.K.: BirdLife International (Conservation Series 4).

Collins, N. M., Sayer, J. A. and Whitmore, T. C., eds. (1991) The conservation atlas of tropical forests: Asia and the Pacific. London: Macmillan.

Corbet, G. B. and Hill, J. E. (1992) The mammals of the Indomalayan Region: a systematic review. Oxford: Oxford University Press.

CVRER [Committee for Vietnam's Resources and Environmental Research] (1985) Vietnam national conservation strategy (draft). Gland: International Union for Conservation of Nature and Natural Resources.

Davison, G. W. H. (1979) Ecology and behaviour of the Great Argus (Argusianus argus). Kuala Lumpur: Ph.D. thesis, University of Malaya.

Delacour, J. (1977) The pheasants of the world. Hinderhead, U.K.: Spur Publications and the World Pheasant Association.

Delacour, J. and Jabouille, P. (1925) On the birds of Quang-tri, Central Annam; with notes on others from other parts of French Indo-china. Ibis 12(1): 209-260.

Delacour, J. and Jabouille, P. (1931) Les oiseaux de l'Indochine française, 1. Paris: Exposition Coloniale Internationale.

Delacour, J., Jabouille, P. and Lowe, W. P. (1928) On the birds collected during the third expedition to French Indo-china. Part 1. Ibis (12)4: 23-51.

Do Tuoc, Vu Van Dung, Dawson, S., Arctander, P. and MacKinnon, J. (1994) Introduction of a new large mammal species in Vietnam. Hanoi: Ministry of Forestry.

Dutson, G. and Branscombe, J. (1990) Rainforest birds in south-west Ghana. Cambridge U.K.: International Council for Bird Preservation (Study Report 46).

Eames, J. C. and Robson, C. R. (1992) Forest bird surveys in Vietnam 1991. Cambridge, U.K.: International Council for Bird Preservation (Study Report 51).

Eames, J. C., Robson, C. R., Nguyen Cu and Truong Van La (1989) Vietnam Forest Project. Pheasant surveys 1988. Unpublished report to ICBP.

ICBP (1992) Putting biodiversity on the map: priority areas for global conservation. Cambridge, U.K.: International Council for Bird Preservation.

Johns, A .D. (1986) Recovery of a Peninsular Malaysian rainforest avifauna following selective timber logging: the first twelve years. Forktail 4: 89-106.

Karr, J. R. (1981) Surveying birds in the tropics. Studies Avian Biol. 6: 548-553.

King, B. F., Dickinson, E. C. and Woodcock, M. W. (1975) A field guide to the birds of South-East Asia. London: Collins.

Lambert, F. R. (1990) Avifaunal changes following selective logging of a north Bornean rain forest. Aberdeen: University of Aberdeen (Report to the Danum Valley Management Committee, Sabah Foundation and the Socioeconomic Research Unit of the Prime Minister's Department).

Lambert, F. R. (1992) The consequences of selective logging for Bornean lowland forest birds. Phil. Trans. R. Soc. Lond. B 335: 443-457. 
MacKinnon, J. and MacKinnon, K. (1986) Review of the protected areas system in the Indomalayan Realm. Gland and London: International Union for Conservation of Nature and Natural Resources.

MacKinnon, J. and Vu Van Dung (1992) Draft management plan for Vu Quang Nature Reserve, Huong Khe district, Ha Tinh province, Vietnam. Unpublished report to Ministry of Forestry.

Ministry of Forestry (1991) Vietnam forestry sector review: tropical forestry action programme. Hanoi: Ministry of Forestry.

Nguyen $\mathrm{Cu}$ and Eames, J. C. (1993) The distribution and status of pheasants in Vietnam. Pp.20-27 in D. Jenkins, ed. Pheasants in Asia 1992. Reading: World Pheasant Association.

Oustalet, M. E. (1898) Notice sur un espèce, probablement nouvelle, de faisan de l'Annam. Bull. Mus. Hist. Nat. Paris 4: 258-261.

Robson, C. R., Eames, J. C., Newman, M., Nguyen Cu and Truong Van La (1991) Forest bird surveys in Vietnam 1989/90: final report. Unpublished report to the International Council for Bird Preservation.

Robson, C. R., Eames, J. C., Nguyen Cu and Truong Van La (1993) Further recent records of birds from Viet Nam. Forktail 8: 25-52.

Rozendaal, F., Nguyen Cu, Truong Van La and Vo Quy (1991) Notes on Vietnamese pheasants, with description of female plumage of Lophura hatinhensis. Dutch Birding 13: 12-17.

Safford, R. and Duckworth, W. (1988) A wildlife survey of Marojejy Nature Reserve, Madagascar. Cambridge U.K.: International Council for Bird Preservation (Study Report 40).

Sibley, C. G. and Monroe, B. L. (1990) Distribution and taxonomy of birds of the world. New Haven and London: Yale University Press.

Thai Van Trung (1985) The development of a protected area system in Vietnam (condensed from an original paper presented in French). Pp.30-31 in J. W. Thorsell, ed. Conserving Asia's natural heritage. Gland, Switzerland, and Cambridge, U.K.: International Union for Conservation of Nature and Natural Resources.

Thirgood, S. J. and Heath, M. F. (1994) Global patterns of endemism and the conservation of biodiversity. Pp.207-227 in P. L. Forey, C. J. Humphries and R. I. Vane-Wright, eds. Systematics and conservation evaluation. Oxford: Clarendon Press (Systematics Association Special Volume 50).

Verner, J. (1985) Assessment of counting techniques. Pp.247-302 in R. F. Johnston, ed. Current ornithology, 2. New York: Plenum Publishing Corporation.

Vu Tu Lap and Taillard, C. (1994) An atlas of Vietnam. Paris: RECLUS - La Documentation Française.

Vu Van Dung, Pham Mong Giao, Nguyen Ngoc Chinh, Do Tuoc, Arctander, P. and MacKinnon, J. (1993) A new species of living bovid from Vietnam. Nature 363: 443445.

WCMC (1993) 1994 IUCN Red List of threatened animals. Cambridge, U.K.: IUCN (The World Conservation Union).

Williamson, W. (1945) On some birds from Thailand, etc. Ibis 87: 52-69.

JONATHAN C. EAMES

BirdLife International Vietnam Programme, Ministry of Forestry, 123 Lo Duc, Hanoi, Vietnam

FRANK R. LAMBERT

Species Survival Commission, IUCN, 219 Huntingdon Road, Cambridge CB3 oDL, U.K. 